\title{
THE BEARING CAPACITY OF FLOATING ICE PLATES SUBJEGTED TO STATIC OR QUASI-STATIC LOADS*
}

\author{
By Arnold D. KerR \\ (Visiting Professor, Department of Civil and Geological Engineering, Princeton University, \\ Princeton, New Jersey 08540, U.S.A.)
}

\begin{abstract}
This paper contains a critical survey of the literature on the bearing capacity of floating ice plates. It consists of a discussion of general questions, a critical survey of analytical attempts to determine the bearing capacity of floating ice plates and a survey of field and laboratory tests on floating ice plates and their relation to the analytical results. It concludes with a systematic summary of the results, a discussion of observed shortcomings, and suggestions for needed investigations.

RÉsumé. La capacité de porter des charges statiques ou quasi-statiques des plaques de glace flottantes. L'étude contient une revue critique de la littérature au sujet de la capacité de porter des charges, des plaques de glace flottantes. Une introduction consacrée à une discussion de questions générales précède une revue critique des approches analytiques tentées pour déterminer la capacité de portage, puis une revue des expériences effectuées sur le terrain et en laboratoire sur les plaques de glace flottantes, ainsi que leur relation avec les résultats analytiques. L'article conclut sur un résumé systématique des résultats, une discussion des insuffisances observées et des suggestions pour les nouvelles recherches nécessaires.

Zusammenfassung. Die Tragfähigkeit von Eisdecken unter statischen oder quasi-statischen Lasten. Der Artikel enthält eine kritische Durchsicht der Literatur über die Tragfähigkeit von Eisdecken. Nach einer einleitenden Diskussion allgemeiner Fragen werden die analytischen Ansätze zur Bestimmung der Tragfähigkeit sowie die Feld- und Laborversuche an Eisdecken in ihrer Beziehung zu den analytischen Ergebnissen kritisch überprüft. Schliesslich folgt eine systematische Übersicht der Ergebnisse, eine Diskussion festgestellter Unstimmigkeiten und Vorschläge für notwendige Untersuchungen.
\end{abstract}

\section{INTRODUGTION}

Frozen lakes and rivers have been utilized since early times for transportation and storage purposes. In Russia railroad tracks have been placed over frozen rivers, in the absence of bridges, since about 1890 (Sergeyev, 1929). Floating ice plates are increasingly utilized as airfields for the landing of aircraft (Moskatov, 1938; Sharp, 1947; Assur, 1956; Stearns, 1957; Linell, 1958), as platforms for storage in logging operations (Duff, I958; Rose and Silversides, 1958), as platforms for the construction of river structures (Marchuk and Mitta, 1966; Vishniyakov and Silantiyev, 1970), as off-shore drilling platforms in the northern regions (Daily, I969), and as aids in various other civilian and military operations (Banin, I 96o; Chikovskiy, I965; Lysukhin, I968; Röthlisberger, I968; U.S. Air Force. Alaskan Air Command, I968; Herbert, 1970). The successful defense of Leningrad during World War II was greatly facilitated by the "ice road" over Lake Ladoga (Gouré, I964, relevant pages are listed in the index on p. 360 under "Ice-road"). The recent oil discoveries in northern Alaska have increased the interest in the Arctic ice cover for off-shore drilling purposes.

A rational utilization of floating ice plates for all these activities require the knowledge of their bearing capacity when they are subjected to loads of short and long duration. Such information is also needed for the design of icebreakers (Jansson, 1956; Popov and others, I 967).

Field observations reveal that when a vehicle is small and relatively heavy, it may break through the ice plate immediately after placement. In such cases, the plate response may be considered elastic up until failure. When the vehicle is relatively light, at the instant of loading the ice plate deforms elastically, but sustains the load. However, as time progresses, the ice plate continues to deform in creep, especially in the vicinity of the vehicle, and after a certain time interval the vehicle may break through the ice.

* Research supported by the U.S. Army Cold Regions Research and Engineering Laboratory. 
In the past, numerous attempts have been made to determine the bearing capacity of floating ice plates subjected to vertical loads. Particularly since World War II, many papers containing test data and related analyses have been published. However, in spite of all these publications, there is as yet no reliable analytical method for predicting the bearing capacity of floating ice plates subjected to static or dynamic loads. This is particularly the case for floating ice plates reinforced by pressure ridges, a phenomenon often encountered in the Arctic (Kovacs, 1972; Weeks and Kovacs, unpublished), for which not even test data can be located in the literature.

One of the main reasons for the lack of dependable methods for determining the breakthrough loads of ice plates is that the lower surface of an ice plate is always subjected to the freezing temperature of about $0^{\circ} \mathrm{C}$, at which the mechanical properties of ice vary drastically with small changes of temperature. Other reasons are: the dependence of the mechanical properties of ice plates upon the rate of freezing, the velocity of the water below the plate during the freezing process, the salinity of ice, etc. Discussions of the mechanical properties of ice have recently been presented by Voytkovskiy (1960), Weeks and Assur (1967, 1969), Lavrov (1969), and Bogorodskiy and others (1971).

Another main reason is the lack of communication among the various investigators, partly caused by language barriers. This has resulted in the duplication of analyses and tests, often rendered useless because of the same shortcomings. Also, the introduction of incorrect solutions for floating ice plates and their subsequent utilization for comparison with test data have not helped in solving the problem under consideration.

The purpose of this paper is to present a critical survey of the literature on the bearing capacity of floating ice sheets. First, the various analytical attempts to determine the bearing capacity are reviewed, grouped according to the "failure criterion" used. This is followed by a discussion of test data and their relation to the analytical results. The paper concludes with a systematic summary of results, a discussion of observed shortcomings, and recommendations for needed investigations. It is hoped that this survey and summary of results will establish a sense of direction in the investigations and will contribute towards the development of effective methods for determining the bearing capacity of floating ice plates.

\section{ANALOgy METHOD}

This method for predicting the bearing capacity of a floating ice plate subjected to a static vertical load, discussed by Korunov (1939-40, 1940), is based on the notion of an analogy of two plates. Korunov assumed that the ice plates under consideration are homogeneous and isotropic and that for two plates with thicknesses $h_{1}$ and $h_{2}$ the corresponding failure moments in cylindrical bending are

$$
M_{1}=\frac{\sigma_{\mathrm{f}} h_{1}^{2}}{6}, \quad M_{2}=\frac{\sigma_{\mathrm{f}} h_{2}^{2}}{6} .
$$

Assuming that the failure stress $\sigma_{\mathrm{f}}$ for the two plates is the same, it follows that

$$
\frac{M_{1}}{M_{2}}=\frac{h_{1}^{2}}{h_{2}^{2}} .
$$

Considering the effect of two different loads, $P_{\mathrm{I}}$ acting on the plate with thickness $h_{\mathrm{I}}$ and $P_{2}$ acting on the plate with thickness $h_{2}$, Korunov assumed that $M$ is proportional to $P$ and obtained from Equation (2)*

$$
\frac{P_{1}}{P_{2}}=\frac{h_{1}^{2}}{h_{2}^{2}}
$$

* Note that Equation (3) was used before by Moskatov (1938, p. 51). 
Equation (3) may be rewritten as follows:

$$
P_{\mathrm{a}}=A h^{2}
$$

where $A=P_{2} / h_{2}{ }^{2}$ and $P_{\mathrm{a}}$ is the allowable load. According to the above method, if an allowable load $P_{2}$ of an ice plate of thickness $h_{2}$ is known (from a test), then the allowable load $P_{\mathrm{a}}$ of an ice plate of different thickness may be computed if the $\sigma_{\mathrm{f}}$ values are the same for both plates. Thus, the coefficient $A$ in Equation (4) is to be determined from a specific test.

Some shortcomings in the derivation of Equation (4) were discussed by Lagutin and Shulman (1946). Note also that in a floating ice plate the bending stress distribution is usually not linear across the plate thickness (Kerr and Palmer, 1972) and therefore the use of Equations (I) may not be admissible.

Nevertheless, because of its extreme simplicity and its agreement with various test results, Equation (4) found wide popularity, as shown in the following table (valid for $P_{\mathrm{a}}$ in metric tonnes and $h$ in centimeters).

Table I. Values of $A$ in Equation (4)

Source

$\left.\begin{array}{l}\text { Korunov (1940) } \\ \text { Peschanskiy (1967) }\end{array}\right\}$

Lebedev (1940) $\}$

Zubov (1942)

Instructions of the Engineering Committee of the Red Army dated 1946

Lysukhin (1968)

$\begin{array}{cl}\text { Vehicle type } & \begin{array}{c}A \\ \mathrm{Mg} \mathrm{cm}^{-2} \\ 0.01\end{array} \\ & 0.0166 \\ & \\ \text { wheeled vehicles } & 0.007 \mathrm{o} \\ \text { racked vehicles } & 0.0123 \\ \text { wheeled vehicles } & 0.0082 \\ \text { racked vehicles } & 0.0123\end{array}$

To demonstrate the use of Equation (4) let us determine the necessary ice thickness for the crossing of a river by a truck weighing 36 metric tonnes, according to Korunov (1940). Using Equation (4) the necessary ice thickness is

$$
h=\sqrt{ } \mathrm{roo} \sqrt{ } 3^{6}=10 \times 6=60 \mathrm{~cm} .
$$

Additional examples of the use of Equation (4) are presented by Moskatov (1938), Lysukhin (1968) and Gusev (r96r).

In order to take into consideration the effects of temperature, the dimensions of load distribution, and the salinity of the ice, Zubov modified Equation (4) as follows:

$$
P_{\mathrm{a}}=K M s A h^{2}
$$

where $K, M$ and $s$ are the corresponding correction coefficients. For a discussion of this extension the reader is referred to Zubov (1942) and Lagutin and Shulman (1946).

Based on field experience with fresh-water ice, Korunov (1956) modified Equation (4) by introducing a correction coefficient $n$ which takes into consideration the condition of the ice as follows:

$$
P_{\mathrm{a}}=\frac{A h^{2}}{n} .
$$

In the above formula $A=0.0$ I tonne $/ \mathrm{cm}^{2}$, and $n$ is related to $\sigma_{\mathrm{f}}$ for $T<-7^{\circ} \mathrm{C}$ as shown in Table II.

Table II. Values of $n$ in Equation (6)

$\begin{array}{lccccc}\sigma_{\mathrm{f}} \mathrm{kg} / \mathrm{cm}^{2} & 5 & 12 & 17 & 25 & 38 \\ n & 4.8 & 2.0 & 1.4 & 1.0 & 0.6\end{array}$




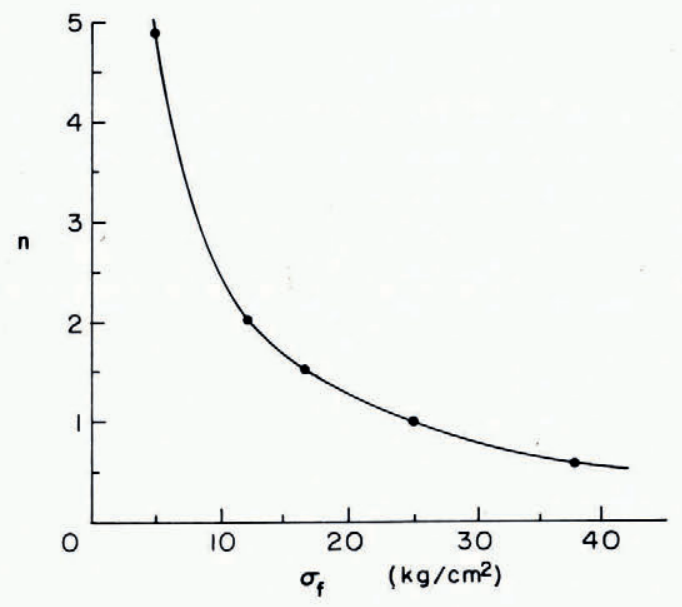

Fig. I. A plot of Korunov's correction coefficient $n$ as a function of failure stress.

A graph of these values is shown in Figure 1. It should be noted that this graph may be presented by the equation

$$
n=\frac{25 \mathrm{~kg} / \mathrm{cm}^{2}}{\sigma_{\mathrm{f}}} .
$$

Substituting it into Equation (6), we obtain for $T<-7^{\circ} \mathrm{C}$

$$
P_{\mathrm{a}}=\frac{\sigma_{\mathrm{f}} h^{2}}{2500}
$$

if $P_{\mathrm{a}}$ is in tonnes, or, if $P_{\mathrm{a}}$ is in kilograms,

$$
P_{\mathrm{a}}=0.4 \sigma_{\mathrm{p}} h^{2} .
$$

The values $\sigma_{\mathrm{f}}$ were stipulated by Korunov (1956) for five types of ice. Korunov (1956) also introduced another correction coefficient for thaw temperatures. For details and examples, the reader is referred to Korunov's paper.

Method based on the BENDing theORY of ElAStic Plates AND THE CRITERION $\sigma_{\max }=\sigma_{\mathrm{f}}$

This method of predicting the bearing capacity of a floating plate subjected to loads of short duration, consists of the following three steps:

(i) Determination of the maximum stress $\sigma_{\max }$ in the floating ice plate due to a given load, assuming that the ice plate is elastic.

(ii) Determination of the load $P_{\mathrm{cr}}$ at which the first crack occurs, utilizing the criterion

$$
\sigma_{\max }=\sigma_{\mathrm{f}} \text {. }
$$

(iii) Correlation of $P_{\mathrm{cr}}$ with the breakthrough load $P_{\mathrm{f}}$. This step, disregarded by many investigators, is needed because, according to field tests, for various plate geometries the occurrence of the first crack does not cause breakthrough; therefore for these cases $P_{\mathrm{f}}>P_{\mathrm{cr}}$.

In the criterion given by Equation (8), $\sigma_{\mathrm{f}}$ is the "failure stress". It is usually obtained by loading a floating ice beam to failure and then computing the largest bending stress at which it failed. In the located literature, $\sigma_{\max }$ is determined using the classical bending theory of thin elastic plates. These results are reviewed below. 
The response of a homogeneous and isotropic elastic plate that rests on a liquid and is subjected to a static vertical load $q$ is described by the partial differential equation

$$
D \nabla^{4} w+\gamma w=q
$$

where $w(x, y)$ is the plate deflection at $(x, y), D$ is the flexural rigidity of the plate, and $\gamma$ is the weight per unit volume of the liquid.

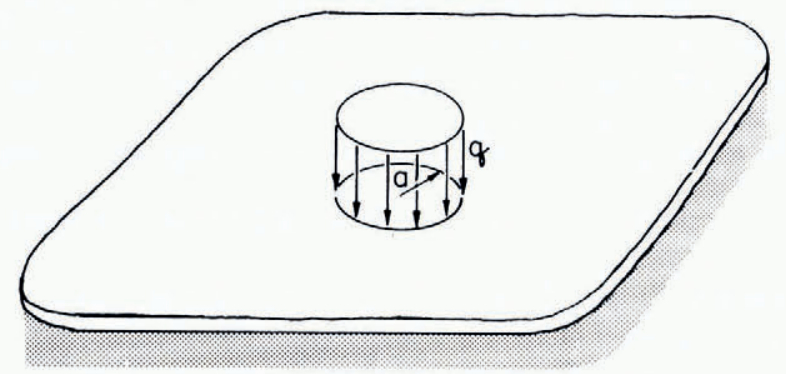

Fig. 2. A floating ice plate subjected to a distributed load $q$ over a circular area of radius a.

Solutions for the infinite plate subjected to a concentrated load $P$, and to a load uniformly distributed over a circular area, were presented by Hertz (1884). Bernshteyn (1929) utilized this discussion for the determination of the allowable load for an infinite ice plate. Using the criterion given by Equation (8), in conjunction with the solution for an infinite plate subjected to a uniform load over a circular area as shown in Figure 2, Bernshteyn obtained

$$
P_{\mathrm{cr}}=\frac{\mathrm{I}}{3(\mathrm{I}+v) C(\alpha)} \sigma_{\mathrm{f}} h^{2}
$$

where $\nu$ is Poisson's ratio for the plate material, $C(\alpha)$ is a given function of $\alpha=a / l$, as shown in Figure 3, $a$ is the radius of the circular area subjected to the uniform load $q=P / \pi a^{2}$,

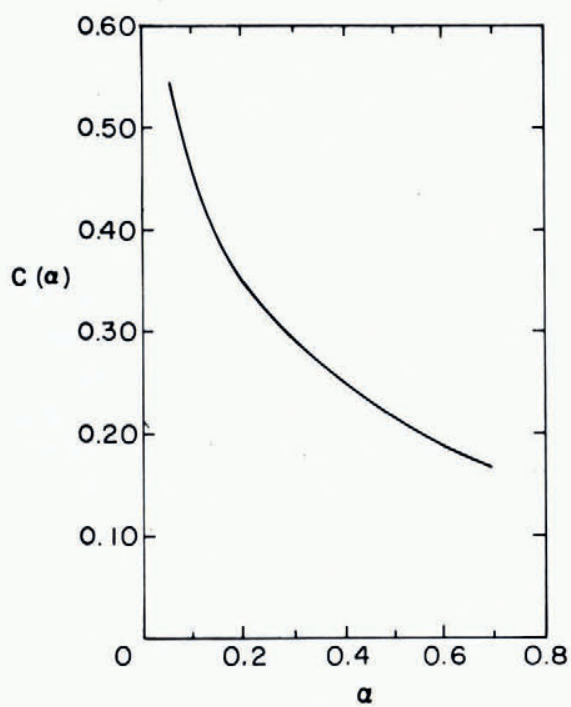

Fig. 3. Graph of $C(\alpha)$ against $\alpha$. This is a modified graph. In the original version (Bernshteyn, 1929) $C(\alpha)$ is presented for $P$ in tonnes, $h$ in meters and $\sigma$ in $\mathrm{kg} \mathrm{cm}^{-2}$. 
$l=(D / \gamma)^{\frac{1}{4}}$, and $D=E h^{3} /\left[12\left(\mathrm{I}-\nu^{2}\right)\right]$. If $\sigma_{\max }=\sigma_{\mathrm{f}}$ is a valid criterion, then $P_{\mathrm{cr}}$ is the load intensity at which the plate cracks.

To demonstrate the use of Equation (Ioa) Bernshteyn computed the $\sigma_{\max }$ due to a railroad car weighing $24 \mathrm{Mg}$ for a $70 \mathrm{~cm}$ thick ice plate as follows.

Assuming that for Volga ice $E=550$ ooo Mg/m² and $\nu=\mathrm{r} / 3$, he obtained

$$
l=(D / \gamma)^{\frac{1}{4}}=\mathrm{I} \mathrm{I} .50 \mathrm{~m} \text {. }
$$

He then assumed that the effect of the weight of the railroad car may be represented by a load uniformly distributed over a circular area with radius $a=1.54 \mathrm{~m}$. Hence, $\alpha=a / l=0.134$. From Figure 3 it follows that $C(\alpha)=0.4^{1}$. For the above values Equation (1oa) yields

$$
\sigma_{\max }=\frac{24000 \times 3 \times(4 / 3) \times 0.417}{(70)^{2}} \mathrm{~kg} / \mathrm{cm}^{2}=8.16 \mathrm{~kg} / \mathrm{cm}^{2}=800 \mathrm{kN} / \mathrm{m}^{2} \text {. }
$$

The next step is to check whether $\sigma_{\max } \leqslant \sigma_{\mathrm{f}}$. For additional numerical analyses, refer to Bernshteyn (1929).

Other numerical examples, based on the Bernshteyn solution, were presented by Volkov (1940) and by Bregman and Proskuryakov (1943; part IV, section 7).

The determination of the load $P_{\mathrm{cr}}$ for a floating infinite plate based on Equations (8) and (9) and the assumption that the load $q=P /\left(\pi a^{2}\right)$ is distributed uniformly over a circular region of radius $a$, was also presented by Wyman (1950), Kubo (1958), and Savel'yev (1963, section 5). Wyman obtained for the load $P_{\text {cr }}$ the expression

$$
P_{\text {cr }}=\frac{\pi \alpha}{3(\mathrm{I}+\nu) \mathrm{kei}^{\prime} \alpha} \sigma_{\mathrm{f}} h^{2} .
$$

This is identical to Equation (roa) noting that

$$
C(\alpha)=\frac{\operatorname{kei}^{\prime} \alpha}{\pi \alpha} .
$$

The determination of $P_{\text {cr }}$, assuming that the uniform load is distributed over a square area with sides $b$, was obtained by Golushkevich and included in his doctoral dissertation*. The derived expression yields loads which are very close to those obtained from Equations (roa) or (rob).

Solutions for an infinite plate were also presented in the books by Schleicher (1926), Korenev (1954), Korenev (1960), and Korenev and Chernigovskaya (1962).

A solution for the infinite plate subjected to a row of equidistant loads was presented by Westergaard (1923) in terms of a trigonometric series. Solutions to similar problems (periodic load distribution), also in terms of trigonometric series, were presented by Lewe (1923), Müller (1952), and Panfilov (1963[a], 1964[a]). The book by Shekhter and Vinokurova (1936) discusses related problems.

Since Equation (9) is linear, it appears that when the plate is subjected to several loads, the method of superposition should be used. This idea was demonstrated by Kerr (1959[b]) for the solution of the floating plate subjected to a row of equidistant loads. A major advantage of this approach is that the distribution of the loads on the floating plate may be aribtrary, whereas the use of trigonometric series is suitable only when the loads act along straight lines, all loads along a line are of the same intensity and distribution and the distance between them is the same.

The analysis of floating ice plates for arbitrary load distributions may be greatly simplified by utilizing influence surfaces (Timoshenko and Woinowsky-Krieger, 1959). Such charts were presented by Pickett and Ray (I95I) for concrete pavements. Influence surfaces for

* This dissertation entitled "O nekotorykh zadachakh teorii izgiba ledyanogo pokrova [On some problems of the theory of bending of floating ice plates]" dates from 1944 and is referred to by various Soviet authors without information of the institution to which it was submitted. 
bending moments, more suitable for ice-plate problems, were presented by Palmer (unpublished). Palmer's charts may also be used for the determination of the load distribution on a plate that yields the largest possible bending moment. An attempt to solve such a problem without influence surfaces was made by Nevel and Assur (1968). They considered the problem of the most unfavorable distribution of crowds on a floating ice plate from the point of view of bearing capacity, based on Equation (8). Using influence surfaces, this problem was recently analyzed by Palmer (unpublished).

Bernshteyn's Equation (roa) is shown as a solid line in Figure 4. Shulman (1946) simplified Equation (I oa) by replacing the curve for $0.07<\alpha<0.65$ with a straight line described by the expression

$$
P_{\mathrm{cr}}=0.375^{\sigma_{\mathrm{f}}}\left(h^{2}+7.8 a(\gamma / E)^{1 / 4} h^{5 / 4}\right) .
$$

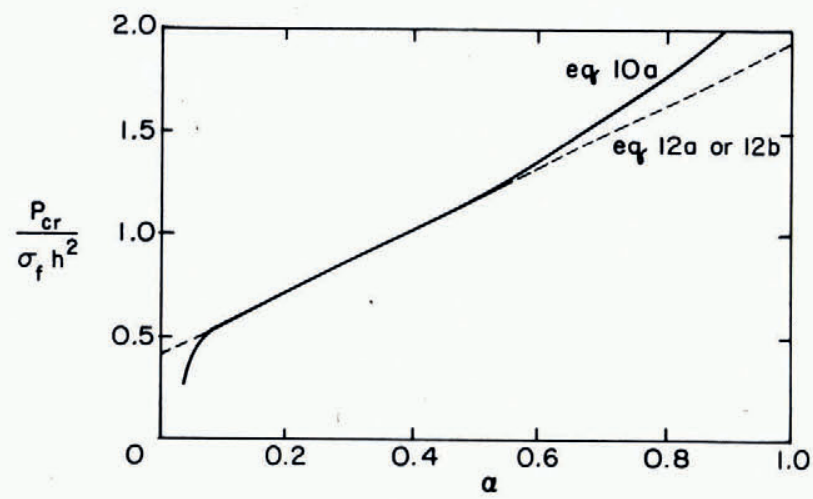

Fig. 4. Comparison between Equation ( 10 ) and proposed simplified relations.

Based on the idea of a straight-line approximation, Panfilov ( $1960[\mathrm{~b}]$ ) proposed the expression

$$
P_{\mathrm{cr}}=0.375(\mathrm{I}+4 . \mathrm{I} \alpha) \sigma_{\mathrm{f}} h^{2} .
$$

It should be noted that Panfilov's approximation, Equation (12b), is the same as the one presented by Shulman, since for $\nu=0.3$

$$
4 \cdot \mathrm{I} \frac{a h^{2}}{l}=4 \cdot \mathrm{I} \frac{a\left(12\left(\mathrm{I}-\nu^{2}\right) \gamma\right)^{1 / 4} h^{2}}{\left(E h^{3}\right)^{1 / 4}} \approx 7.4 a\left(\frac{\gamma}{E}\right)^{1 / 4} h^{5 / 4} \text {. }
$$

The following approximation was also proposed by Panfilov (196o[b]):

$$
P_{\mathrm{cr}}=\frac{2 \pi \sigma_{\mathrm{p}} h^{2}}{3(\mathrm{I}+\nu)\left(0.682+0.0 \mathrm{I} g \alpha^{2}-\ln \alpha\right)} .
$$

However, since it is not much simpler than the exact expression, Equation (I oa), its usefulness is questionable.

Panfilov (1964[b]) attempted to derive another approximate expression for $P_{\mathrm{cr}}$, assuming that the deflections of a floating ice plate subjected to a concentrated force $P$ may be expressed approximately as:

$$
w(x, y)=w_{0} \exp \left(-\frac{\lambda}{\sqrt{ } 2}(x+y)\right)\left(\sin \frac{\lambda x}{\sqrt{ } 2}+\cos \frac{\lambda x}{\sqrt{ } 2}\right)\left(\sin \frac{\lambda y}{\sqrt{ } 2}+\cos \frac{\lambda y}{\sqrt{ } 2}\right)
$$

where

$$
\lambda=(\gamma / D)^{1}
$$


From the equilibrium equation

$$
P=4 \gamma \int_{0}^{\infty} \int_{0}^{\infty} w \mathrm{~d} x \mathrm{~d} y .
$$

Panfilov determined the only unknown, $w_{0}$, as

$$
w_{0}=\frac{P}{8(\gamma D)^{\frac{1}{2}}} \text {. }
$$

Comparing the resulting $w(x, y)$ with the exact solution and finding that the agreement is relatively close, Panfilov determined the bending moments using the relations (Timoshenko and Woinowsky-Krieger, I959, p. 81)

$$
\left.\begin{array}{l}
M_{x}(x, y)=-D\left(\frac{\partial^{2} w}{\partial x^{2}}+\nu \frac{\partial^{2} w}{\partial y^{2}}\right) \\
M_{y}(x, y)=-D\left(\frac{\partial^{2} w}{\partial y^{2}}+\nu \frac{\partial^{2} w}{\partial x^{2}}\right)
\end{array}\right\},
$$

and the approximate $w(x, y)$ given in Equation (15). For the bending moments under the load $P$, he obtained

$$
M_{x}(\mathrm{o}, \mathrm{o})=M_{y}(\mathrm{o}, \mathrm{o})=\frac{(\mathrm{I}+v) P}{8} .
$$

Equating this expression with $M_{\mathrm{cr}}=\sigma_{\mathrm{f}} h^{2} / 6$, Panfilov obtained, for $v=1 / 3$, the expression

$$
P_{\mathrm{er}}=\sigma_{\mathrm{f}} h^{2} \text {. }
$$

At this point, it should be noted that the fact that the approximate and exact deflections are relatively close (in the sense of comparing two graphs) does not imply that the second derivatives are also close. Thus, for example, whereas the exact solution for the classical plate theory based on Equation (9) yields infinite moments under the concentrated load $P$, Panfilov's approximate solution yields the finite value shown in Equation (20). This point may be demonstrated further by comparing the graphs for the bending moment $M_{x}(x, 0)$ based respectively on Equation (15) and on the exact solution. It may be shown that although the deflections are relatively close, the bending moments based on Equation (I5) do not approximate closely the actual bending moments, especially in the vicinity of the load.

Other approximate solutions for the infinite plate were discussed by Korunov (1967). Assuming that Bernshteyn's Equation (roa) is the correct expression for predicting the bearing capacity, Korunov proposed the empirical expression (for $h$ in $\mathrm{cm}$ )

or

$$
\left.\begin{array}{l}
P_{\mathrm{cr}}=\left(0.06 \mathrm{Mg} / \mathrm{cm}^{2}\right) / \alpha h^{2} \\
P_{\mathrm{cr}}=\left(60 \mathrm{~kg} / \mathrm{cm}^{2}\right) \alpha h^{2}
\end{array}\right\},
$$

and then showed that for special situations, this agrees with the results of Equation (roa). Noting that Equation (22) is based on $\sigma_{\mathrm{f}}=24 \mathrm{~kg} / \mathrm{cm}^{2}=2350 \mathrm{kN} / \mathrm{m}^{2}$, it follows that

$$
\frac{P_{\mathrm{cr}}}{\sigma_{\mathrm{f}} h^{2}}=2.5 \alpha \text {. }
$$

Note that, according to Equation (22), for a given $\sigma_{\mathrm{f}}, P_{\mathrm{cr}}$ is proportional to the second term in Equation (12a) or (12b), namely to $h^{5 / 4}$, whereas Equation (2 I), derived for $\alpha=0$, is proportional to the first term, namely to $h^{2}$. Note also the difference between Equation (7), suggested by Korunov, and Equation (2 I), derived by Panfilov. A comparison of various approximate expressions for $P_{\text {cr }}$ with the one based on Equation (IOa) is shown in Figure 5 .

* To determine the stresses under the load, the correction derived by Westergaard may be used (Timoshenko and Woinowsky-Krieger, 1959, p. 275). 


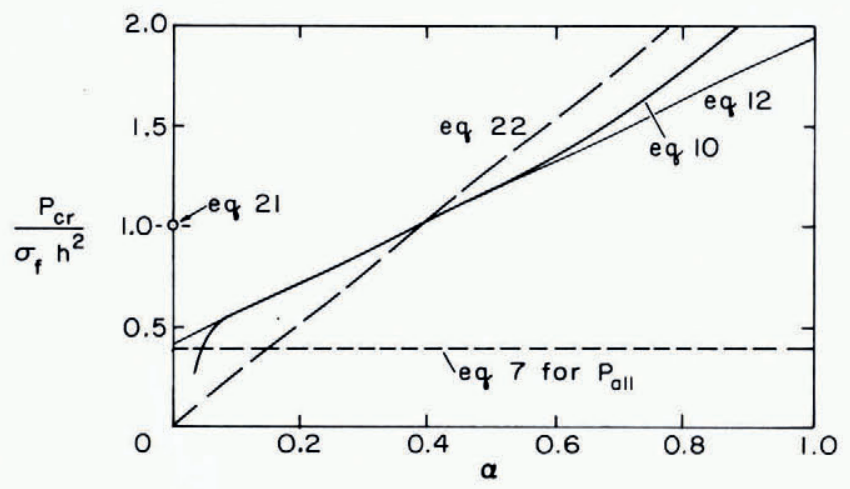

Irig. 5. A comparison of approximations for P'.r with exact calues.

It appears that, instead of deriving numerous approximate expressions for Equation ( I oa) that differ substantially from each other and are not much simpler than the exact expression,* it should first be established whether Equation (roa) is suitable for predicting the bearing capacity of floating ice plates for loads of short duration. This and related questions will be discussed later.

Solutions for the floating semi-infinite plate with a free edge subjected to lateral loads were presented by Shapiro (1943) and by Golushkevich in his doctoral dissertation (see footnote on p. 234) using Fourier integral methods. Shapiro's results were verified and extended by Nevel (1965).

Zylev (1950), using Equation (8), presented calculations of the bearing capacity of a floating semi-infinite ice plate subjected along its free edge to vertical and horizontal loads. However, Zylev's approximate solution of Equation (9) for the vertical load, recently included in a number of books (e.g. Korzhavin, 1962; Butyagin, 1966) is incorrect, as shown below.

For the semi-infinite plate shown in Figure 6, Zylev assumes an approximate solution of the form

$$
w(x, y)=[\cosh (\alpha x)+\Gamma \sinh (\alpha x)] f(y)
$$

where

$$
\left.\begin{array}{ll}
\Gamma=+\mathrm{I} & \text { for } x<0 \\
\Gamma=-\mathrm{I} & \text { for } x>0
\end{array}\right\} .
$$

Substituting Equation (23) into Equation (9) with $q=0$, he obtains an ordinary differential equation of fourth order for $f(y)$. To determine the four constants, Zylev uses two regularity conditions at infinity and the conditions

$$
\begin{gathered}
M_{y}(x, \mathrm{o})=\mathrm{o} \\
P=\int_{0}^{\infty} \int_{-\infty}^{\infty} \gamma w \mathrm{~d} x \mathrm{~d} y .
\end{gathered}
$$

It should be noted that for the chosen deflection surface given by Equation (23), $\partial w / \partial x$ is discontinuous along the $y$-axis, which is not the case in an actual ice plate. Also, $\partial^{3} w / \partial x^{3}$ is discontinuous along the $y$-axis; this implies that for the assumed deflection surface there

* A prospective user of Equation (10) does not have to be familiar with Bessel functions if he utilizes the $C(\alpha)$ graph shown in Figure 3 . 
exists a line load along the $y$-axis. This is in contradiction with the assumed plate load shown in Figure 6. Furthermore, along the free edge, where the largest stresses are anticipated, the boundary conditions for a free edge are not satisfied. Therefore, the validity of Zylev's solution for the semi-infinite plate, even for the determination of an approximate $P_{\mathrm{cr}}$, is questionable.

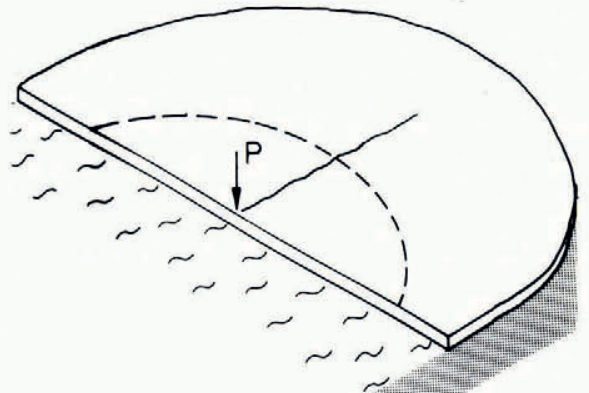

Fig. 6. Floating semi-infinite plate with free edge subjected to load $P$.

According to Zylev's results, the largest bending moment takes place at the point $x=0$ and $y=1.14 D^{4}$. On the basis of this analysis

$$
P_{\text {cr }}=0.8 \lambda[\mathrm{I}-\exp (-\lambda)]^{-1} \sigma_{\mathrm{f}} h^{2}
$$

where

$$
\lambda=0.248 b / D^{1} .
$$

According to Shapiro's results, $\sigma_{\max }$ takes place under the load. Utilizing Equation (8), the load at which the first crack occurs becomes

$$
P_{\mathrm{cr}}=S(\alpha) \sigma_{\mathrm{f}} h^{2}
$$

where $S(\alpha)$ for $\nu=0.36$ is given in Figure 7 .

Panfilov ( $1960[\mathrm{a}]$ ) compared the values of the load $P_{\mathrm{cr}}$, for the infinite plate as well as the semi-infinite plate. The corresponding graphs are shown in Figure 7. This comparison shows that the $P_{\text {cr }}$ for the semi-infinite plate, according to Zylev (dashed line), is much higher than the $P_{\text {er }}$ according to Shapiro and Golushkevich. If o $<b / l<0.5$, it is even higher than the

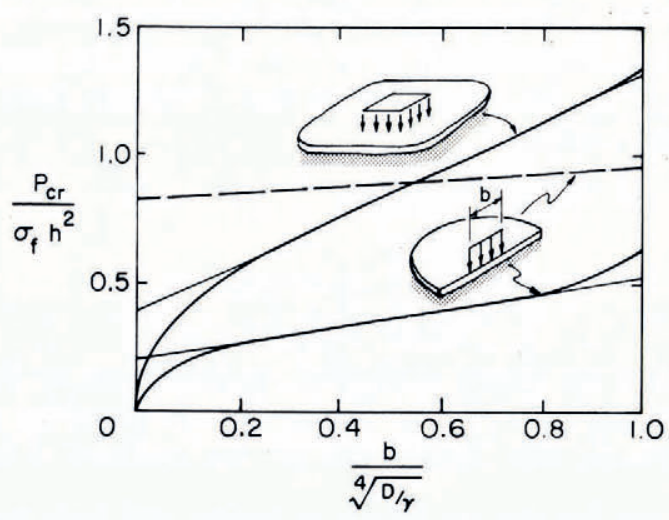

Fig. 7. Comparison of analytical results. 
$P_{\text {cr }}$ of the infinite plate. In view of this comparison and the obvious errors contained in Zylev's solution, it is suggested that Equation (27) should not be used for the analysis of the semi-infinite plate with a free edge.

According to Panfilov (1960[a]) it follows from. Figure 7 that for $0.07<b / l<\mathrm{r}$.o, the value of $P_{\mathrm{cr}}$ for the infinite plate is about 2.45 times the value of $P_{\mathrm{cr}}$ for the semi-infinite plate. A more precise relationship is shown in Figure 8.

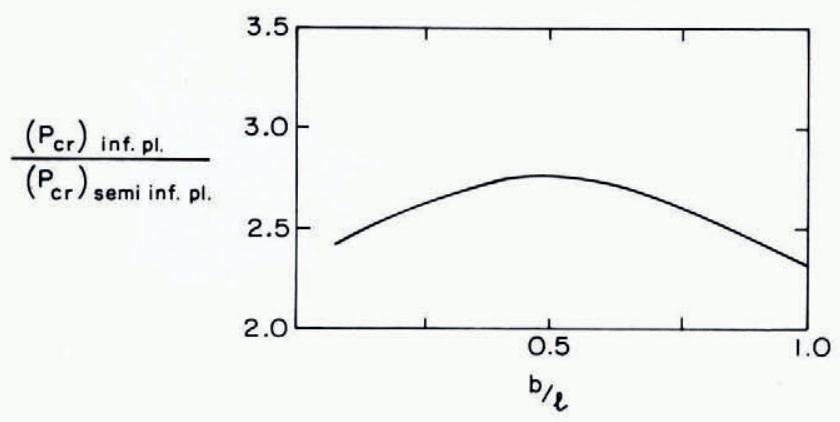

Fig. 8. Relation between critical loads for the infinite plate and semi-infinite plate.

On the basis of the graph for the semi-infinite plate shown in Figure 7, Panfilov (196o[a]) proposed the following approximate expression for the interval $0.07<b / l<\mathrm{I}$ :

$$
P_{\text {cr }}=0.16(\mathrm{I}+2.30 b / l) \sigma_{\mathrm{f}} h^{2} .
$$

Panfilov (1964[b]) also attempted to derive an approximate expression for $P_{\mathrm{cr}}$ for the problem shown in Figure 6, assuming that

$$
w(x, y)=w_{0} \exp \left(-\frac{\lambda}{\sqrt{ } 2}(x+y)\right)\left(\sin \frac{\lambda x}{\sqrt{ } 2}+\cos \frac{\lambda x}{\sqrt{ } 2}\right) \cos \frac{\lambda y}{\sqrt{ } 2} .
$$

However, the result obtained, similar in form to Equation (2 I), is of questionable value. The objections raised in connection with Equation (2I) also apply here. It should also be noted that the deflection surface, Equation (31), does not satisfy Equation (9) or the boundary conditions along the free edge, where the stresses are determined for use in Equation (8).

The semi-infinite plate subjected to equidistant loads $P$ along the free edge was analyzed by Westergaard (1923). Similar problems were solved by Panfilov (1963 [b], [d]). The books of Shekhter and Vinokurova (1936) and Korenev and Chernigovskaya (1962) also contain solutions to related problems.

The solution for the semi-infinite plate, simply supported along the straight edge and subjected at any point of the plate to a concentrated force $P$, as shown in Figure 9, was derived by Kerr (1959[a]). Using the method of images, the following exact closed-form solution was obtained:

$$
w(x, y)=\frac{P \lambda^{2}}{2 \pi k}\left\{\operatorname{kei}\left[\lambda \sqrt{ }\left\{\left(x-x_{0}\right)^{2}+y^{2}\right\}\right]-\operatorname{kei}\left[\lambda \sqrt{ }\left\{\left(x+x_{0}\right)^{2}+y^{2}\right\}\right]\right\} .
$$

Palmer (unpublished) utilized this solution to construct a number of influence surfaces for bending moments.

A numerical solution for the semi-infinite plate, clamped along the edge and subjected to a force $P$ at a point on the plate, was presented by Korenev (1960).

An analysis of a floating infinite strip, free along both edges and subjected to a lateral load, utilizing the Fourier integral method, was presented by Shapiro (1942). Detailed results for similar problems were presented by Panfilov (1966[a], 1970[a]). 


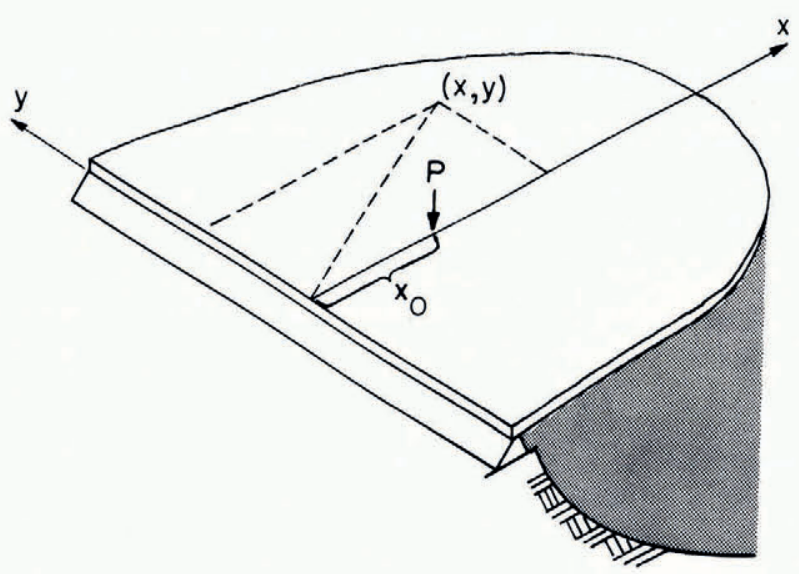

Fig. 9. Floating semi-infinite plate. simply supported along the straight edge and subjected to a load Pat $\left(x_{0}, o\right)$.

The solution for a floating infinite strip, simply supported along both edges and subjected to a concentrated force $P$ at any point on the plate, was presented by Kerr (1959[a]), utilizing the method of images. The resulting deflection was given as a rapidly converging infinite series of fundamental solutions for the infinite plate. A solution for this problem was presented by Westergaard (1923) in terms of Fourier series. Nevel (1965) presented a solution in terms of a Fourier integral. A solution for a similar problem was presented by Panfilov (r966[a]) also using the Fourier integral method.

Kashtelyan (1960) presented calculations for the direct determination of $P_{\mathrm{f}}$ (that is by eliminating step (iii) in the above procedure) which are based on the observation that the carrying capacity is reached when the wedges which form initially break off. However, Kashtelyan's solution for the wedge-shaped plate on which his calculations are based, may not be accurate enough, as shown in the following.

For the rectangular corner plate with free edges, shown in Figure Io, Kashtelyan assumed an approximate solution

$$
w(x, y)=f \exp [-\alpha(x+y)] \cos (\alpha x) \cos (\alpha y)
$$

where $\alpha$ and $f$ are unknown parameters.

From the condition

$$
P=\int_{0}^{\infty} \int_{0}^{\infty} \gamma w \mathrm{~d} x \mathrm{~d} y
$$

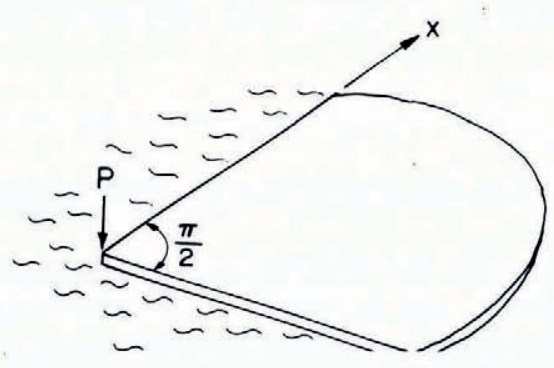

Fig. Io. Floating quarter-infinite plate subjected to a load $P$ at its apex. 
Kashtelyan obtained

$$
f=4 \alpha^{2} P / \gamma \text {. }
$$

Then, utilizing the Bubnov-Galerkin method, for a one-term approximation he used

$$
\int_{0}^{\infty} \int_{0}^{\infty}\left(\nabla^{4} w+\gamma w / D\right) w \mathrm{~d} x \mathrm{~d} y=0
$$

and determined from it

Thus, according to Equation (35)

$$
\alpha=(\gamma / 4 D)^{4}
$$

$$
f=2 P /(\gamma D)^{\frac{1}{2}} .
$$

It should be noted that the above analysis contains errors: because the assumed deflection given by Equation (33) does not satisfy the boundary conditions of zero moments and zero shearing forces along the free boundary, Equation (36) is not complete. Also, the work term of the force $P$ is missing. According to the principle of virtual displacements, the proper Bubnov-Galerkin equation for a one-term approximation $w=f w_{1}(x, y)$, where $f$ is the only unknown, is

$$
\begin{gathered}
\int_{0}^{\infty} \int_{0}^{x}\left(D \nabla^{4} w+k w\right) w_{1} \mathrm{~d} x \mathrm{~d} y+\int_{0}^{x} M_{y}(x, \mathrm{o}) \frac{\hat{c} w_{1}}{\partial y}(x, \mathrm{o}) \mathrm{d} x-\int_{0}^{x} V_{y}(x, \mathrm{o}) w_{1}(x, \mathrm{o}) \mathrm{d} x+ \\
+\int_{0}^{\infty} M_{x}(\mathrm{o}, y) \frac{\hat{c} w_{1}}{\hat{c} x}(\mathrm{o}, y) \mathrm{d} y-\int_{0}^{x} V_{x}(\mathrm{o}, y) w_{1}(\mathrm{o}, y) \mathrm{d} y-P w_{1}(\mathrm{o}, \mathrm{o})=\mathrm{o}
\end{gathered}
$$

where $M_{x}$ and $M_{y}$ are given by Equations (19) and

$$
\left.\begin{array}{l}
V_{x}(\mathrm{o}, y)=-D\left[\frac{\partial^{3} w}{\partial x^{3}}+(2-v) \frac{\partial^{3} w}{\partial x \partial y^{2}}\right]_{x=0} \\
V_{y}(x, 0)=-D\left[\frac{\partial^{3} w}{\partial y^{3}}+(2-v) \frac{\partial^{3} w}{\partial x^{2} \partial y}\right]_{y=0}
\end{array}\right\} .
$$

Note, however, that the purpose of Equation (36) is not to determine $f$ but $\alpha$.

Comparing the $f$-value given by Equation $\left(3^{8}\right)$ with the corresponding value of the exact solution of an infinite plate, $f=P / 8(\gamma D)^{1}$, and the (incorrect) approximate solution by Zylev (1950) for a semi-infinite plate, $f=P / 2(\gamma D)^{\frac{1}{2}}$, Kashtelyan (1960), without justification, generalized his solution for a wedge of any opening angle $\phi$ (Fig. I I) by assuming that

$$
f=\frac{\mathrm{I}}{2}\left(\frac{\pi}{\phi}\right)^{2} \frac{P}{(\gamma D)^{\frac{1}{2}}}
$$

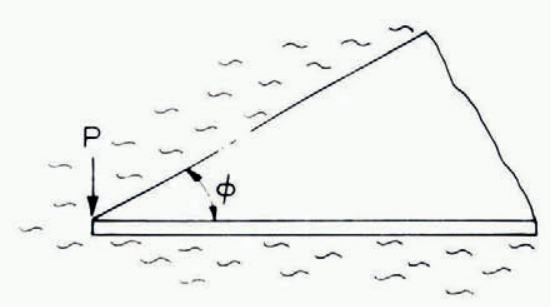

Fig. 1:. Floating wedge loaded at its apex. 
an equation which satisfies Equation $\left(3^{8}\right)$ for $\phi=\pi / 2$ and the other two cases $(\phi=2 \pi$ and $\phi=\pi$ ) mentioned above. Utilizing Equation (8), he then obtained for the "failure load" of a floating wedge plate of opening angle $\phi$ the expression

$$
P_{\mathrm{f}}=\left(\frac{\phi}{\pi}\right)^{2} \frac{\mathrm{I}}{0.966} \sigma_{\mathrm{f}} h^{2} .
$$

Note that, according to field observations made by Kashtelyan (1960), when $\phi<120^{\circ}$, $P_{\text {cr }}=P_{\mathrm{f}}$. Thus, according to Equation (42) for a floating wedge with $\phi=\frac{1}{2} \pi$, as shown in Figure 10, the breakthrough load is

$$
P_{\mathrm{f}}=\left(\frac{\mathrm{I}}{2}\right)^{2} \frac{\sigma_{\mathrm{f}} h^{2}}{0.966}=0.259 \sigma_{\mathrm{f}} h^{2} .
$$

Observations in the field indicate that the failure mechanism of a semi-infinite plate subjected to a force $P$ at the free edge proceeds as follows: First a radial crack forms, which starts under the load and propagates normal to the free boundary. This is followed by the formation of a circumferential crack that causes final failure, as shown in Figure 12.

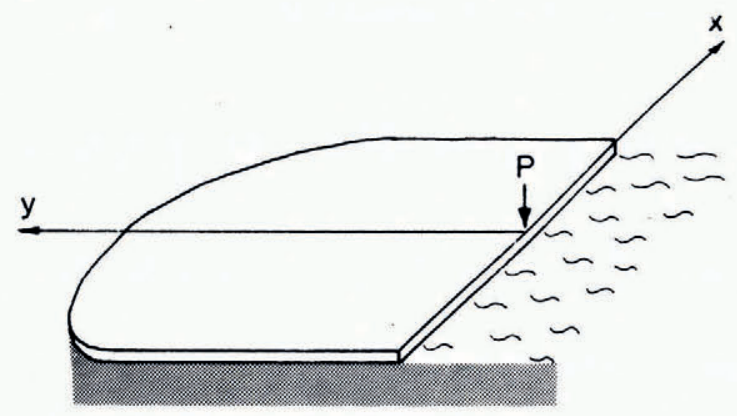

Fig. 12. Failure mechanism of a floating semi-infinite plate subjected to a load $P$ at the free edge.

According to Kashtelyan, the failure load for this case is equal to the failure load of two free-floating wedges, each of opening angle $\phi=\pi / 2$. Namely,

$$
P_{\mathrm{f}}=2 \times 0.259 \sigma_{\mathrm{f}} h^{2}=0.5^{1} 8 \sigma_{\mathrm{p}} h^{2} .
$$

In a similar way, Kashtelyan determined the $P_{\mathrm{f}}$ for an infinite plate. Assuming that $n$ is the number of radial cracks and that the $n$ formed wedges are all of equal opening angle, i.e. $\phi_{n}=2 \pi / n$, as shown in Figure 13, the following expression for the failure load results:

$$
P_{\mathrm{f}}=n\left(\frac{2 \pi}{n} \frac{\mathrm{I}}{\pi}\right)^{2} \frac{\sigma_{\mathrm{f}} h^{2}}{0.966}=\frac{4 \sigma_{\mathrm{f}} h^{2}}{0.966 n} .
$$

Noting that $n=2 \pi / \phi_{n}$, this expression may also be written as

$$
P_{\mathrm{f}}=2.08\left(\frac{\phi_{n}}{\pi}\right) \sigma_{\mathrm{f}} h^{2}
$$

where $\phi_{n}$ is the opening angle of the formed wedges. Note that with decreasing $\phi_{n}$ the load $P_{\mathrm{f}}$ in Equation (44) decreases and that the above approach does not take into consideration the effect of the wedge-in moments along the cracks.

Kashtelyan showed that the results of $\mathrm{I}_{5} \mathrm{O}$ tests on floating ice plates agree closely with the bearing capacity values based on Equations (43) and (44). In view of the errors discussed above, however, this agreement is not convincing. 


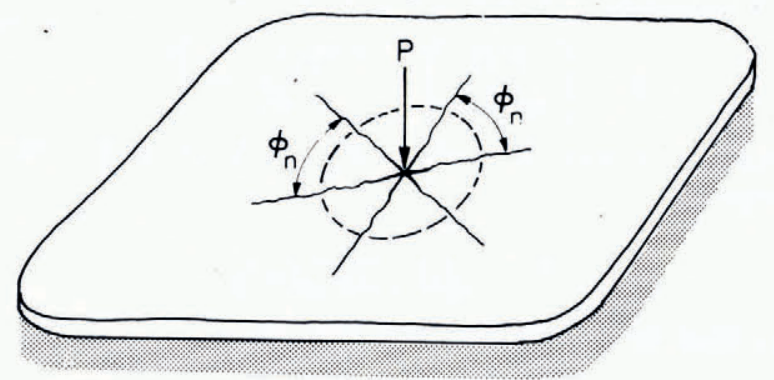

Fig. 13. Failure mechanism for a large floating ice plate subjected to a load $P$.

An approximate solution for the quarter plate with free edges loaded at the apex, was also presented by Westergaard (1948).

An exact, closed-form solution for the quarter plate simply supported along the edges and subjected at any point of the plate to a concentrated force $P$ was presented by Kerr (r 959 [a]), using the method of images.

The response of a narrow infinite wedge resting on a liquid base, as a beam problem, is described by an ordinary differential equation with a variable coefficient. This equation was solved by Dieudoneé (unpublished) by means of the Laplace method of integration. Nevel (1958) solved it using the method of Frobenius. Nevel's solution consists of a sum of four infinite series which were evaluated by Nevel (I96I) and are presented as graphs. An approximate solution for large values of $x$ was presented by Hetényi (1946).

An early attempt to determine the bearing capacity of a floating ice plate utilizing a floating wedge solution was described by Papkovich (1962, p. 424-26). In this analysis it was assumed that the wedge response is governed by a modified bending theory of beams by stating the base parameter as (Fig. 14)

and the flexural rigidity as

$$
k(x)=\gamma[b+2 x \tan (\phi / 2)]
$$

$$
E I(x)=\frac{E h^{3}}{\mathrm{I} 2\left(\mathrm{I}-\nu^{2}\right)}(b+2 x \tan (\phi / 2))
$$

where $\gamma$ is the weight per unit volume of the liquid. The term $\left(I-\nu^{2}\right)$ was apparently included to get plate action for the wedge. The deflection was assumed to have the form

$$
w(x)=A \exp (-\lambda x) \cos (\lambda x)
$$

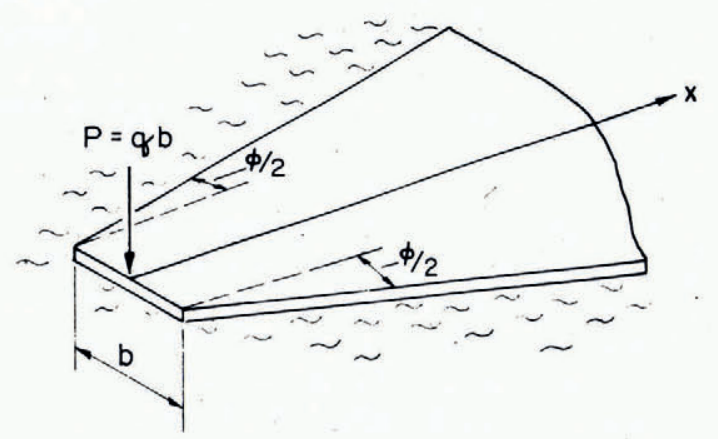

Fig. I4. Floating wedge-shaped plate subjected to a load $p=q b$. 
where

$$
\lambda=\left[\frac{k(x)}{4 E I(x)}\right]^{\frac{1}{3}}=\left[\frac{3 \gamma\left(\mathrm{I}-\nu^{2}\right)}{E h^{3}}\right]^{\frac{1}{4}}
$$

and the unknown constant $A$ was determined by minimizing the total potential energy. Substituting the determined

$$
A=\frac{2 \lambda^{2} P}{\gamma[\lambda b+\tan (\phi / 2)]}
$$

into Equation (47), yielded the deflection

$$
w(x)=\frac{2 \lambda^{2} P}{\gamma[\lambda b+\tan (\phi / 2)]} \exp (-\lambda x) \cos (\lambda x) .
$$

The bending moment was

$$
M(x)=-E I \frac{\mathrm{d}^{2} w}{\mathrm{~d} x^{2}}=-E I(x) 2 A \lambda^{2} \exp (-\lambda x) \cos (\lambda x)
$$

and the stresses in the upper and lower fibres were obtained as

$$
\sigma(x)= \pm \frac{M(x)}{W(x)}= \pm \frac{E h}{\mathrm{I}-\nu^{2}} A \lambda^{2} \exp (-\lambda x) \cos (\lambda x) .
$$

From the condition $\mathrm{d} \sigma / \mathrm{d} x=0$, the position of the largest stress $x=\pi /(4 \lambda)$, was determined. Substituting this value into the above equation, it follows that

$$
\sigma_{\max }=\frac{0.15}{\mathrm{I}-\nu^{2}} A \lambda^{2} E h .
$$

Utilizing the failure criterion given by Equation (8), namely $\sigma_{\max }=\sigma_{\mathfrak{f}}$, it follows from Equation (5 1 ), using Equations (48) and (49), that

$$
P_{\mathrm{f}}=\frac{\lambda b+\tan (\phi / 2)}{0.9} \sigma_{\mathrm{p}} h^{2} \text {. }
$$

Noting Equation (48), the above expression for the failure load of a wedge of opening angle $\phi$ may also be written as

$$
P_{\mathrm{f}}=\left\{\left[\frac{b}{0.9}\left[3\left(\mathrm{I}-\nu^{2}\right) \gamma / E\right]^{\mathrm{r} / 4}\right] h^{5 / 4}+\left[\frac{\tan (\phi / 2)}{0.9}\right] h^{2}\right\} \sigma_{\mathrm{f}} .
$$

Pointing out that an ice plate breaks under the weight of an icebreaker into wedges and that $P_{\mathrm{f}}$ in Equation (53) is of the form

$$
P_{\mathrm{f}}=A_{1} h^{2}+A_{2} h^{5 / 4},
$$

Papkovich suggested that Equation (54) be utilized for the determination of an empirical expression for the breakthrough load of an ice plate by determining the parameters $A_{1}$ and $A_{2}$ from field test data.

It should be noted that although Equation (53) is only an approximation (for example, the corresponding bending moment at $x=0$ is not zero), its dependence upon $h$ is identical with that in Equations (12a) and (12b) for the infinite plate and Equation (30) for the semiinfinite plate, respectively. Even the term $b(\gamma / E)^{\frac{1}{2}}$ appears in the proper place. This observation will be of importance when discussing the test data presented by Panfilov ( $1960[\mathrm{a}])$.

For solutions to other plate problems for which response is governed by Equation (9), reference is made to the books by Schleicher (1926), Shekhter and Vinokurova (1936), Korenev (1954, 1960) and Korenev and Chernigovskaya (1962), to the survey articles by Korenev (1957, 1969) and Savel'yev (1969), and to the literature on the analysis of highway and airport pavements. 
When a floating ice plate seals the liquid base, then in addition to the buoyancy pressure $k w(x, y)$, the liquid exerts also a uniform pressure $p^{\star}$ on the plate. In these cases, an additional condition has to be imposed on the solution to reflect this situation. The unknown $p^{\star}$ is determined from this condition.

If the assumption that the liquid is sealed and incompressible is justified, then this additional condition is

$$
\iint_{A} w \mathrm{~d} A=\mathrm{o}
$$

where the integration extends over the domain of the plate $A$.

Floating plates subjected to Equation (55) were analyzed by Nevel (1963) and Kerr $(1965,1966)$. Kerr and Becker (1967) solved plate problems by assuming that the sealed liquid is compressible. They showed that the effect of the sealed liquid depends not only upon its relative compressibility but also upon the sealed volume: the larger the sealed volume, the smaller the sealability effect. This result suggests that the use of Equation (55) for the analysis of an ice plate that covers a river or a lake, as suggested recently by Mahrenholtz (1966) is not justified.

The analyses reviewed in this section are based on Equation (9), which is the differential equation for a homogeneous and isotropic thin elastic plate. In an actual floating ice plate, the material parameters vary across the thickness of the plate; hence, the floating ice plate is inhomogeneous. This variation is very pronounced in sea-ice plates as well as in a plate whose upper surface is subjected to very low air temperatures.

An early attempt to take into consideration the variation of Young's modulus $E$ by Bregman and Proskuryakov (1943, p. 73) is incorrect because the investigators did not take into consideration that when $E$ varies across the plate thickness the resulting stress distribution is not linear.

According to recent papers by Newman and Forray (I962), Panfilov (1966[b]), and Assur (1967), when Young's modulus $E$ varies with the plate thickness $h$, and Poisson's ratio $\nu$ is assumed to be constant, Equation (9) is still valid if the flexural rigidity is

$$
D=\frac{\mathbf{I}}{\mathbf{I}-\nu^{2}} \int_{-z_{0}}^{h-z_{0}} z^{2} E(z) \mathrm{d} z
$$

and the position of the reference plane is determined from the condition

$$
\int_{-z_{0}}^{h-z_{0}} z E(z) \mathrm{d} z=0 .
$$

In order to utilize the available solutions of Equation (9) for nonhomogeneous plates with $E=E(z)$, it had to be shown that, except for Equation $(56)$, the corresponding boundary conditions are the same as those for homogeneous plates. This was done recently by Kerr and Palmer (1972), who systematically formulated this problem utilizing Hamilton's principle in conjunction with the three-dimensional theory of elasticity.

Kerr and Palmer (1972) also showed that even though the plane-section hypothesis is assumed, the resulting bending stress distributions are not linear across the plate thickness. An example is shown in Figure 15. This finding suggests that the well-known stress equation

$$
\sigma_{\max }=\frac{6 M_{\max }}{h^{2}}
$$

utilized by various investigators in conjunction with Equation (8), or for the determination of the failure stress $\sigma_{\mathrm{f}}$ from tests on floating ice beams, may not be applicable in general. 

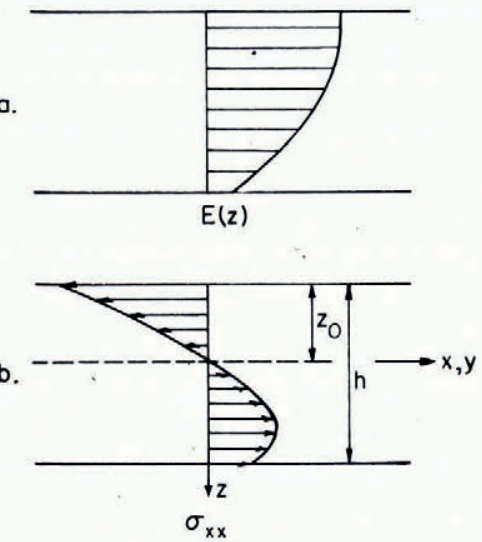

Fig. 15. Stress distribution in an ice plate for the shown $E(z)$.

\section{Method BASED ON VISCO-ELASTIC THEORIES}

It was observed in the field that for loads which do not cause an instantaneous breakthrough, the ice plate deforms at first elastically and then, with progressing time, continues to deform in creep, especially in the vicinity of the load.

Two characteristic deflection-versus-time curves for fixed loads $P$ are shown in Figure 16. Curve I represents the case when, after a time, the rates of deformation diminish and the ice plate and load come to an apparent standstill. This curve corresponds to a safe load for any length of time under consideration. Curve II represents the case when, after a time, the rates of deformation increase and after a time $t_{\mathrm{f}}$ the load breaks through. Thus, the load that corresponds to curve II is safe for time $t<t_{\mathrm{f}}$, but then it has to be moved to another location to prevent breakthrough.

The above field observations suggest that, for an analytical determination of breakthrough loads which do not cause immediate failure, a visco-elastic analysis has to be conducted.

It appears that the small-deformation theory of plates may be sufficient for plates which follow curve I. However, the analysis of plates which respond according to curve II is more complicated because in the vicinity of the load, a region of prime interest, the small deflection theory may not be valid when it is approaching $t_{\mathbf{p}}$. Also, as the plate deflections increase, the plate may start to crack-a phenomenon not predicted by the usual theories of visco-elastic

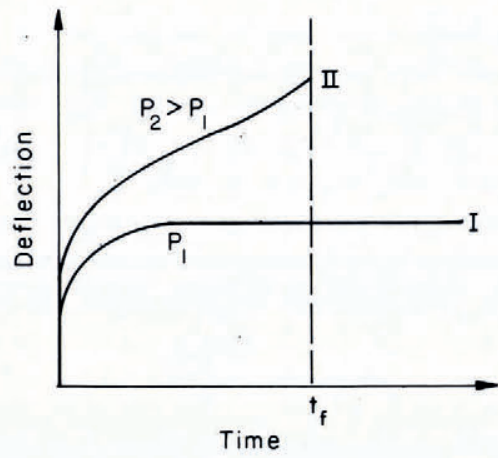

Fig. I6. Two characteristic curves of deflection versus time. 
continua. To predict cracking, a separate failure or crack criterion has to be used. Also, after the first crack takes place, the analysis gets even more involved because of the introduction of additional, often irregular, plate boundaries.

For an analytical determination of a "safe" load $P<P_{\mathrm{f}}$ and a "time to failure" $t_{\mathrm{f}}$, it is desirable to have one visco-elastic theory for floating ice plates which for time $t \doteq$ o yields the elastic response and for $t>0$ yields responses according to curves I or II, depending upon the load and the material parameters of the ice (which in turn depend upon the temperature distribution, salinity, etc.). This theory should be supplemented by a crack or failure criterion valid for the elastic and visco-elastic range.

The elastic theory in conjunction with the crack criterion $\sigma_{\max }=\sigma_{\mathrm{f}}$ discussed above could, if proven correct, be a special case of such a general theory.

Another failure criterion was proposed by Zubov (1942) and by Kobeko and others (1946[b]). On the basis of their test data, they concluded that for loads of short or long duration, a floating ice plate fails under the load when a certain deflection $w_{\mathrm{f}}$ is reached: namely, when

$$
w_{\max }=w_{\mathrm{p}} .
$$

According to Kobeko and others (1946[b]) for this criterion it does not matter whether the plate deflections are purely elastic or visco-elastic, as shown in Figure i 7 .

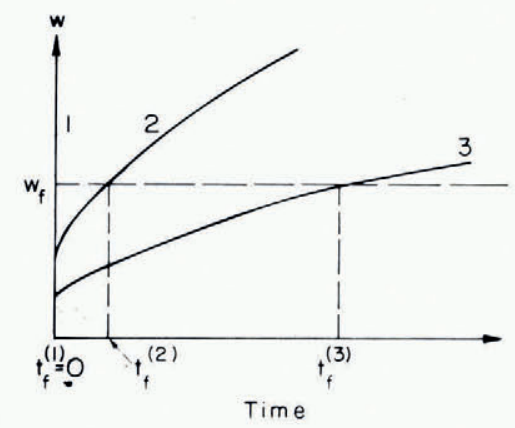

Fig. 17. The failure criterion based on plate deflections.

Equation ( $5^{8}$ ) was also adopted by Savelyev ( 1963 , section 5 ) for the study of the effect of temperature and salinity on the carrying capacity of a floating ice cover.

Panfilov (I96I) proposed the above criterion for floating ice plates which are cracked in the dished area. His justification was that then water begins to flood the upper surface of the plate, with a resulting loss of base pressure in this area. It may be added that the flooding of the upper surface near the load also raises the temperature of the upper layers of the plate to about $0^{\circ} \mathrm{C}$, thus decreasing the strength of the ice in the area of high stresses.

From experiments on floating ice plates with plate thicknesses $h$ from $\mathrm{I}$ to $6 \mathrm{~cm}$ and temperatures from $-3^{\circ} \mathrm{C}$ to $-8.5^{\circ} \mathrm{C}$, Panfilov ( $196 \mathrm{I}$ ) found, for $h$ and $w_{\mathrm{p}}$ in centimeters, that

$$
w_{\mathrm{f}}=2.2 h^{\frac{1}{2}} \text {. }
$$

In this connection note that using the criterion $w_{\max }=w_{\mathrm{f}}$ in conjunction with Equation (59) and the solution for an infinite (uncracked) elastic plate subjected to a concentrated load $P$

$$
w_{\max }=w(0,0)=\frac{P}{8(\gamma D)^{\frac{1}{2}}},
$$


it follows that

or

$$
\frac{P_{\mathrm{f}}}{8(\gamma D)^{\frac{1}{2}}}=2.2 h^{\frac{1}{2}}
$$

$$
P_{\mathrm{f}}=17.6\left[\frac{\gamma E}{12\left(1-\nu^{2}\right)}\right]^{\frac{1}{2}} h^{2} .
$$

Thus, according to Equation (59), the breakthrough load $P_{\mathrm{f}}$ is proportional to $h^{2}$. It may be of interest to note that if the largest deflection of the plate under consideration is expressed by the equation

$$
w_{\max }=\frac{\epsilon P}{(\gamma D)^{\frac{1}{2}}}
$$

where $\epsilon$ is a coefficient, then a $P_{\mathbf{f}}$ expression of the form shown in Equation (54) corresponds to the criterion

$$
w_{\mathrm{f}}=\alpha h^{\frac{1}{2}}+\frac{\beta}{h^{\frac{1}{4}}}
$$

where $\alpha$ and $\beta$ are coefficients.

Test data are needed to establish whether the failure criterion, Equation ( 58$)$, and its special forms Equations (59) or (6I), are indeed valid for elastic as well as visco-elastic deformations.

In the early attempts to take time effects into consideration for floating ice plates, one approach, presented by Bregman and Proskuryakov (1943, p. 53), utilizes the solutions for elastic bending and tries to fit the experimental data by modifying the elastic constants. In another approach presented by the South Manchurian Railway Company* in I94I, the elastic results are multiplied by a time factor, for example $\left(\mathrm{I}+\alpha t^{\beta}\right)$, where $t$ is time and $\alpha$ and $\beta$ are constants to be determined from experimental data. However, these approaches have no rational foundation and their results are of questionable value.

Another early approach is based on a hypothesis by Zubov (1942, p. 49) which states that deflections of ice plates, especially at comparatively high temperatures, are caused mainly by the vertical shearing forces. To verify Zubov's assumption, Zvolinskiy (1946) analyzed a plate resting on a liquid, assuming that the deformations are entirely due to shearing action and that for creep deformations the material obeys Newton's law of viscosity. Although the resulting differential equation was relatively simple, the obtained solution was rather involved because of the prescribed initial conditions. Quoting a translation of Zvolinskiy (1946, p. 21): "In this formula the result is not self evident, and analyzing it does not help us to visualize the picture of the phenomenon".

Zvolinskiy used, for the initial condition, the elastic deflection surface caused by shear only. However, according to the experiments by Bernshteyn (1929, fig. 18 ) shortly after the load is placed, the deflection surface agrees closely with the elastic deflection surface due to bending. Also, since the elastic deflections are relatively small, the effect of assuming that the elastic deformations are zero seems to be negligible compared with the introduced error of assuming shear as the only force responsible for creep deformations. This assumption was made by Kerr (I959[b]), who attempted to simplify Zvolinskiy's analysis in order to study the characteristic features of the creep deformations based on Zubov's hypothesis.

Recorded observations of the effect of static loads on the deformation of floating ice fields, for example by Bernshteyn (1929, p. 48) and Zubov (1942, p. 146), showed that in some cases the rates of deflection decreased after the load was placed and after a certain time interval the

* Translation of report by South Manchurian Railway Company, I941, translated by U. S. Snow, Ice and Permafrost Research Establishment as "Bearing capacity of natural ice cover". (In Studies on river ice; with special reference to the construction of railroad on ice. U.S. Snow, Ice and Permafrost Research Establishment. Translation 50, Part III.) 
plate came to a standstill, whereas in other cases the rates of deflection increased until the plate collapsed under the load as shown in Figure 16 . The observed decreasing and increasing rates of deflection should result from a general formulation of the problem. However, because of the simplifying assumptions made, Kerr (r959[b]) had to set up two separate formulations for the decreasing and increasing rates of deformation, in order to obtain this response. Although some of the resulting solutions did agree with deflection expressions given by Zubov (1942, p. 24; 1945, p. 148), because of the various assumptions made, these results should be used with caution for the determination of breakthrough loads.

The assumption that the predominant deformations of a floating ice sheet are caused by shearing forces was also made by Krylov (1948).

The intense development of the linear theory of visco-elasticity after World War II had its effect also on the formulation of ice-plate problems. In 1947 Golushkevich (referred to by Kheysin (1964)) presented an analysis assuming that ice behaves elastically for volumetric deformations and visco-elastically for deviatoric deformations. His formulation was based on the linear bending theory of plates, linear constitutive equations, and the assumption that the material parameters do not vary across the plate thickness. The obtained equations were linear. The special case of an incompressible material was analyzed in detail.

A general formulation for visco-elastic plates, based on the linear bending theory of plates and the assumption that the constitutive equation is a linear relation of differential operators, was presented by Freudenthal and Geiringer (1958). The utilization of this equation for floating ice plates was discussed by Kheysin (1964). As a special case, Kheysin analyzed an infinite ice plate subjected to a concentrated force $P$, assuming that the ice is incompressible for volumetric deformations and that it responds like a Maxwell body for deviatoric deformations. A similar problem which arises when the load is distributed uniformly over a circular area, was analyzed by Nevel (1966), who also presented graphs and a comparison with the results of a test. Yakunin ( 1970 ) presented solutions for various load distributions, assuming that the ice responds like a four-element model; namely a series combination of a Maxwell and a Kelvin model. Except for the paper by Yakunin, in the above analyses it is assumed that the material parameters are constant throughout the plate.

As discussed in the preceeding section, in an actual floating ice cover the material parameters vary with depth. In an attempt to take this into consideration, Yakunin (1970) derived an approximate formulation for a varying modulus of elasticity and coefficient of viscosity, and solved it for a variety of load distributions. He found that, as in the elastic case, the variation of material parameters across the plate thickness has a profound effect upon the stresses in the ice cover.

A visco-elastic analysis of the ice cover based on Reissner's theory of plates, which takes into consideration the effect of bending as well as shearing forces upon the deformations, was recently presented by Garbaccio ( 1967,1968$)$. Garbaccio assumed that the ice responds like a series combination of a Maxwell and a Kelvin model and that the material parameters are constant throughout the ice plate.

Panfilov (I96I), citing observed short-comings of linear theories, derived a differential equation for floating ice plates, based on the linear bending theory of plates and the nonlinear visco-elastic constitutive equations proposed by Voytkovskiy (1957, 1960). Additional derivations, along the same line, were presented by Panfilov (1970[b]) who, however, gave no solutions to the derived differential equation.

An attempt to analyze the time-dependent stresses of an ice cover, using a non-linear constitutive equation, was presented by Cutcliffe and others (1963).

The linear bending theory and a non-linear constitutive equation was also used by Garbaccio $(1967,1968)$ to analyze ice-plate problems. Garbaccio attempted to obtain an approximate solution of the resulting non-linear formulation by means of a linearization technique. 


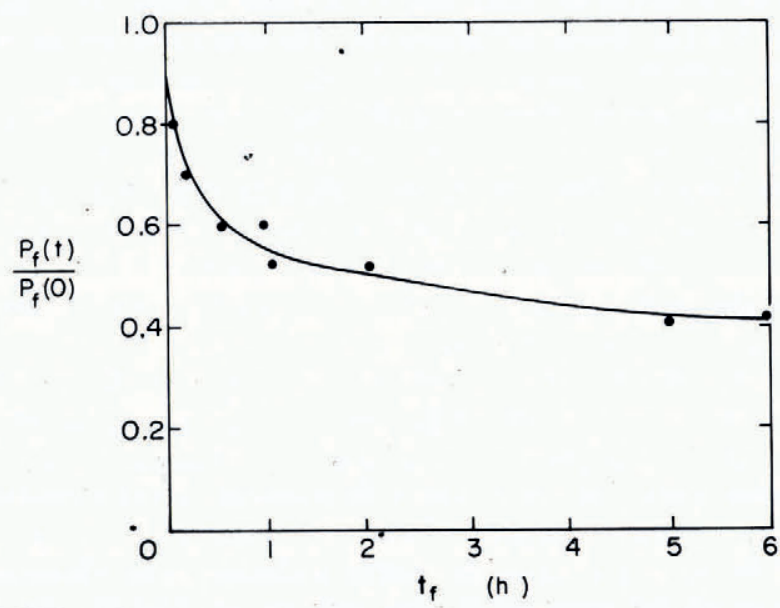

Fig. 18. Failure load as a function of time to failure.

In the absence of reliable analyses for predicting the bearing capacity of ice plates subjected to loads of long duration, Panfilov ( $196 \mathrm{I}$ ), constructed from field test data the graph shown in Figure 18 . In this graph $t_{\mathrm{f}}$ is the time period between placement of the load and breakthrough $P_{\mathrm{f}}(\mathrm{o})$ is the magnitude of the load just sufficient to break through immediately after placement on the plate (at $\left.t_{\mathrm{f}}=0\right)$, as discussed in the previous section, ${ }^{*}$ and $P_{\mathrm{f}}\left(t_{\mathrm{f}}\right)$ is the load that breaks through after a time $t_{\mathrm{f}}$. From the shown graph, it follows that $P_{\mathrm{f}}\left(t_{\mathrm{f}}\right)<P_{\mathrm{f}}(\mathrm{o})$ for $t_{\mathrm{f}}>0$. Thus, for example, a load that has to park safely on the ice plate for $6 \mathrm{~h}$ should be smaller than ${ }_{0.4} P_{\mathrm{f}}(0)$, where $P_{\mathrm{f}}(\mathrm{o})$ is determined from a separate analysis. To represent the graph shown in Figure 18 analytically, Panfilov proposed the expression for $t_{\mathrm{f}}$ in hours,

$$
\frac{P_{\mathrm{f}}\left(t_{\mathrm{f}}\right)}{P_{\mathrm{f}}(\mathrm{o})}=\frac{\mathrm{I}}{\mathrm{I}+0.75_{\mathrm{f}}^{\frac{t^{3}}{3}}} .
$$

Solving this equation, the "safe" storage time is obtained as the time that is smaller than

$$
t_{\mathrm{f}}=\left[\frac{P_{\mathrm{f}}(\mathrm{o})-P_{\mathrm{f}}\left(t_{\mathrm{f}}\right)}{0.75 P_{\mathrm{f}}(\mathrm{o})}\right]^{3} .
$$

A graph similar to the one shown in Figure 18 was also presented and discussed, by Assur $([\mathrm{rg} 62][\mathrm{b}])$.

Korunov (1968) pointed out that Equation (62) was obtained from tests on ice plates under specific conditions. He then proposed the following modification of Equation (63):

$$
t_{\mathrm{f}}=\left[\frac{P_{\mathrm{f}}(\mathrm{o})-P_{\mathrm{f}}\left(t_{\mathrm{f}}\right)}{0.75 P_{\mathrm{f}}(\mathrm{o}) n}\right]^{3} K
$$

where $K$ and $n$ are correction coefficients which take into consideration the shape of the load and the outside temperature.

Other expressions of the type shown in Equation (62) were presented and discussed by Panfilov (1970[b]). For a related discussion refer to Yakunin (1970).

- In the previous section, it is denoted, for brevity's sake, as $P_{\mathrm{f}}$. 


\section{METHODS BASED ON THE YIELD-LINE THEORY OR LIMIT ANALYSIS}

The theory of yield lines was utilized for the analysis of continuously supported plates by Johansson (1947) and Bernell (1952). Persson (1948) used it for the analysis of a floating ice plate. Assuming that the yield-line moment per unit length is $M_{0}$, Persson obtained for the case shown in Figure 2,

$$
P_{\mathrm{f}}=\frac{4 \pi}{(\mathrm{I}+\nu)\left(\mathrm{I}-0.62 \alpha^{\frac{2}{3}}\right)} M_{0} .
$$

Using a similar approach, Assur ([1962][b]) presented, for the breakthrough load, the expression

$$
P_{\mathrm{f}}=\frac{4 \pi M_{0}}{\mathrm{I}-\frac{1}{3}\left(\frac{1}{2} \pi \alpha^{2}\right)^{\frac{1}{3}}} .
$$

The method of limit analysis was used by Meyerhof (1960) for the analysis of the bearing capacity of floating ice plates. Assuming that the ice plate is thin, rigid ideally plastic, that it can, without cracking, resist a full plastic moment $M_{0}$, and that the ice obeys the Tresca yield condition, Meyerhof obtained for the case shown in Figure 2

$$
P_{\mathrm{f}}=3 \cdot 3 \pi\left(\mathrm{r}+\frac{3}{2} \alpha\right) M_{0}, \quad 0.05<\alpha<\mathrm{r} .0 .
$$

Assuming that the floating ice plate prior to failure is cracked radially into numerous wedges, Meyerhof obtained for the same case

$$
P_{\mathrm{f}}=\frac{4 \pi M_{0}}{\mathrm{I}-\frac{1}{2} \alpha}, \quad 0.2<\alpha<\text { I.o. }
$$

In an extensive discussion of Meyerhof's paper, Hopkins (Hopkins and others, I96I) questioned the degree of realism in approximating the mechanical behavior of ice by a rigid perfectly-plastic material. Hopkins, as well as Wood, also questioned the use of the Tresca yield condition.

Recently, Coon and Mohaghegh (1972) also analyzed the floating ice plate by the method of limit analysis, but assumed that the ice obeys Coulomb's law. For the problem shown in Figure 2 they obtained

$$
P_{\mathrm{f}}=2 \pi(2.3+2.9 \alpha) M_{0} \text {. }
$$

Additional results and discussions are presented by Meyerhof (1960) and Coon and Mohaghegh (1972).

Related results were published by Korenev (I96o, part II, § 7) and Serebryanyy (I96o).

It should be noted that the often-used expression for the limit bending moment, $M_{0}=\sigma_{0} h^{2} / 4$, is based on a stress distribution of a homogeneous plate as shown at (a) in Figure 19, whereas, because of the thermal gradient in the plate, the distribution of limit stresses could be, noting Peschanskiy (1945) and assuming that a full plastic moment does exist, as shown at (b) in Figure 19. Also, the assumption that the ice plate can, without cracking, resist a full plastic moment $M_{0}$ may not be realistic, since its formation was not observed in the field. When using yield-line theory, it may be more realistic to work with "cracks" instead of "yield lines" and "wedge-in moments" instead of the "plastic moment $M_{0}$ ", especially along the radial cracks.

A comparison of the various $P_{\mathrm{f}}$ expressions presented above with the formula for $P_{\mathrm{cr}}$ given in Equation (roa) by Bernshteyn is shown in Figure 20. For comparison purposes, it was assumed that $\sigma_{\mathrm{f}}=\sigma_{0}$ and that $M_{\mathrm{o}}=\dot{\sigma}_{0} h^{2} / 4$. Note that a different number in the denominator of $M_{0}$ only shifts a plotted graph vertically.

Note that all graphs of $P_{\mathrm{f}} /\left(\sigma_{0} h^{2}\right)$ against $\alpha$ obtained using plasticity methods show the same characteristics and that they may be represented by a straight line, as in Equations (12a) or (12b). 


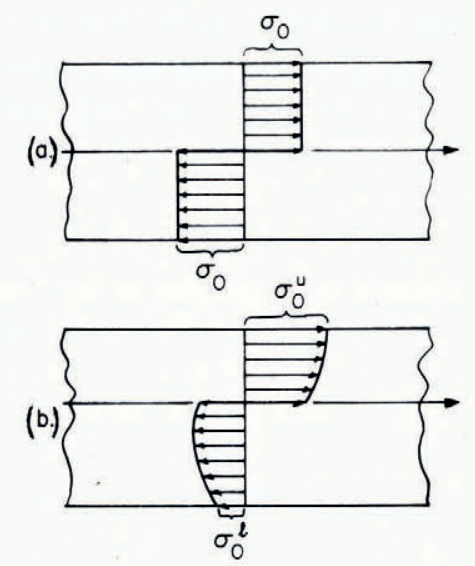

Fig. 19. Development of a full plastic bending moment in a homogeneous plate (a) and effect of a thermal gradient in the plate on this $(b)$.

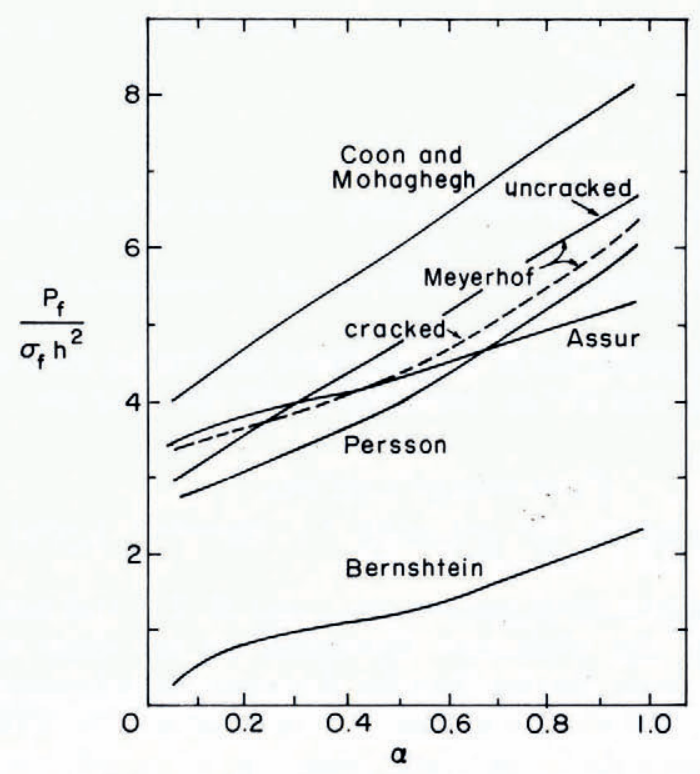

Fig. 20. Comparison of various expressions for $P_{\mathrm{f}}$ with the $P_{\mathrm{cr}}$ deduced by Bernshteyn in Equation (Io).

\section{COMPARISON OF ANALYTICAL AND TEST RESUlTS}

\section{General remarks}

The mechanical properties of ice vary drastically in the vicinity of the melting (or freezing) temperature of about $0^{\circ} \mathrm{C}$. Because the lower surface of a floating ice plate is usually at the freezing temperature, the plate response is obviously affected by this. This effect is especially severe when the upper surface is also subjected to temperatures near $0^{\circ} \mathrm{C}$, because then the temperature throughout the plate is close to the melting temperature.

To demonstrate the variations of temperature with time, consider a floating ice plate subjected for a long time to an air temperature of $-10^{\circ} \mathrm{C}$. Assume that at time $t=0$ the air 
temperature rises to $-\mathrm{I}^{\circ} \mathrm{C}$. Then the corresponding temperature distributions for different times are as shown in Figure $2 \mathrm{I}$. Note that although the temperatures at the top and bottom surfaces are constant for $t>0$, the temperatures throughout the plate vary with time. Hence, if two identical tests are performed before a thermal steady state is established, the results may differ, depending upon the time (after the sudden outside temperature change) when a particular test is conducted.

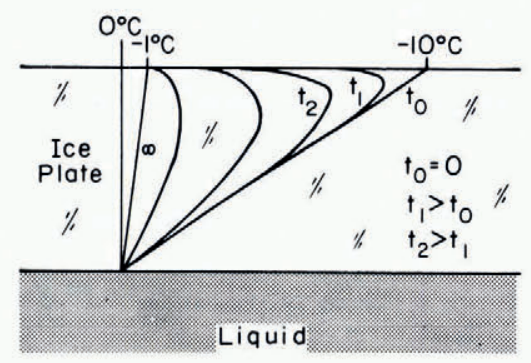

Fig. 21. Temperature distribution in the ice sheet (schematic) for different times.

A similar situation occurs in the floating test beams used for the determination of the failure stress $\sigma_{\mathfrak{f}}$, because, after a beam is cut out from the ice, the side walls come in contact with the rising water and the outside air.

Another thermal problem may arise in a test when an ice cover in the field is loaded by pumping water into a large tank that rests directly on the cover, for then the bottom of the tank, which is made of metal or canvas, rests on the ice, and the upper surface of the ice plate in the contact region is subjected to temperatures near $0^{\circ} \mathrm{C}$ which may differ substantially from the outside air temperature. This type of loading usually causes a change in the stress distribution and a lowering of the strength of the ice in the area where failure usually starts, thus affecting the test results.

These and related questions, such as the effect of a sharp drop of the air temperature, the rate of loading, the penetration of water through the ice plate during loading, etc., have to be considered when the test data of floating ice plates are correlated with corresponding analytical results. In the following, various test results are presented and correlated with analyses discussed previously.

\section{Effect of bending and shearing forces on the deflection of an ice cover}

As shown in the previous sections, an analytical determination of the breakthrough load utilizes a formulation for the ice cover. In order to simplify the necessary analyses, such a formulation contains a number of assumptions. It is essential that the assumptions made be justified, from a physical point of view, since otherwise the analytical results may have no relevance to the actual problem under consideration.

One such assumption, included in the derivation of Equation (9), states that a straight line normal to the reference plane, remains straight and normal to the deformed plane (sometimes called the Kirchhoff hypothesis). Physically, this kinematic assumption implies that the deflections are caused only by bending stresses, and that the effect of shearing forces is negligible. This assumption, discussed at length in books on strength of materials, has been proven to be justified for the elastic response of slender beams and thin plates made of a variety of materials. 
On the other hand, basing his view on field observations, Zubov (I945) suggested that the deflections of an ice cover are mainly caused by shearing forces and hence the effect of bending upon the deflections is negligible.

Because the resulting equations are used for the analytical determination of $P_{\mathrm{f}}$, for additional examples see Panfilov ( $\mathrm{I}_{96} 6_{3}[\mathrm{c}]$ ), it is essential to determine whether Kirchhoff's or Zubov's assumption is to be used for the formulation of ice-cover problems. In this connection, note that the plate deflections due to a load $q$ which is distributed over a circular area, based on Equation (9), are, according to Wyman (1950),

$$
\left.\begin{array}{ll}
w_{\mathrm{I}}(r)=\frac{q \alpha}{\gamma}\left[\frac{\mathrm{I}}{\alpha}+\operatorname{ker}^{\prime}(\alpha) \operatorname{ber}(\lambda r)-\operatorname{kei}^{\prime}(\alpha) \operatorname{bei}(\lambda r)\right], & 0 \leqslant r \leqslant a \\
w_{2}(r)=\frac{q \alpha}{\gamma}\left[\operatorname{ber}^{\prime}(\alpha) \operatorname{ker}(\lambda r)-\operatorname{bei}^{\prime}(\alpha) \operatorname{kei}(\lambda r)\right], & a \leqslant r \leqslant \infty
\end{array}\right\},
$$

where $\lambda=(\gamma \mid D)^{1}$, whereas the differential equation for an ice plate, according to Zubov's hypothesis, is

$$
-G h \nabla^{2} w+\gamma w=q .
$$

where $G$ is the shear modulus and the corresponding deflections are

$$
\left.\begin{array}{ll}
w_{\mathrm{I}}(r)=\frac{q}{\gamma}\left[\mathrm{I}-(\kappa a) K_{\mathrm{I}}(\kappa a) I_{0}(\kappa r)\right], & 0 \leqslant r \leqslant a \\
w_{2}(r)=\frac{q}{\gamma}(\kappa a) I_{\mathrm{I}}(\kappa a) K_{0}(\kappa r), & a \leqslant r<\infty
\end{array}\right\},
$$

where $I_{0}, K_{0}, I_{\mathrm{I}}$ and $K_{\mathrm{I}}$ are Bessel functions and $\kappa=[\gamma /(G h)]^{\frac{1}{1}}$. To show the different nature of the deflection curves based on these two assumptions, the Equations (70) and (72) were evaluated numerically for $h=10 \mathrm{~cm}, \nu=0.3$ and $E=10500 \mathrm{~kg} / \mathrm{cm}^{2}\left(10.7 \mathrm{MN} / \mathrm{m}^{2}\right)$. For $\cdot a / h=\mathrm{I}$ and 5 the corresponding values of $G$ were determined using the condition that the largest deflections $w(0)$ for both theories are equal. The results are shown in Figure 22.

Note that the response of an ice cover according to Zubov is identical to the response of the shear layer in the Pasternak foundation as shown by Kerr (1964).

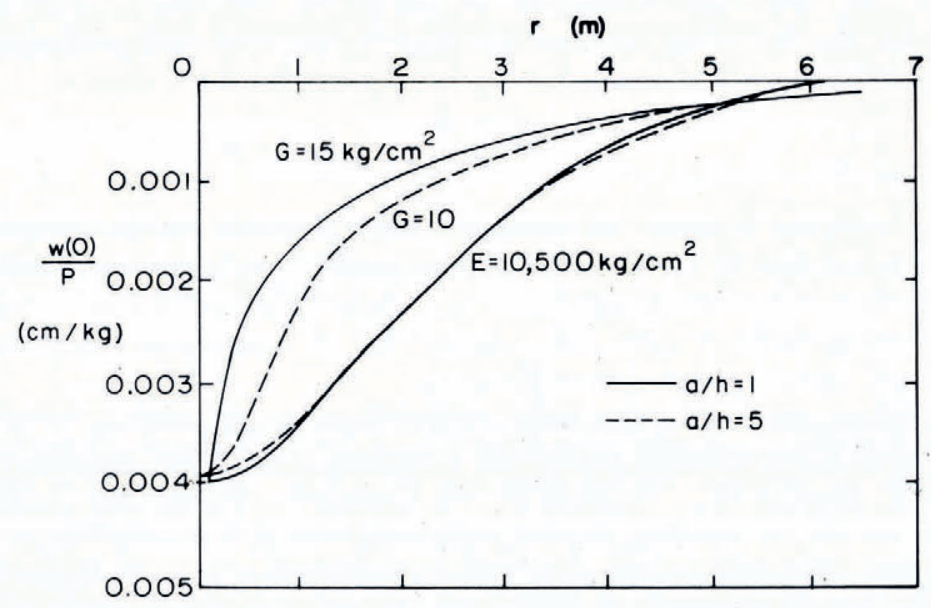

Fig. 22. Deflection curves according to bending and shear theories. 
As early as 1929 , Bernshteyn compared the deflections of an ice field on the river Volga subjected to loads of short duration, at air temperatures of $-15^{\circ} \mathrm{C}<T<-7^{\circ} \mathrm{C}$, with corresponding results based on Equation (9). This comparison is shown in Figure 23. Since the agreement is very close, it was concluded that the use of Equation (9), and hence Kirchhoff's hypothesis, is justified for the formulation of problems of ice plates subjected to loads of short duration.

Shmatkov ( 1968 ) compared test data of an ice plate on lake Baykal, subjected to a vertical load of short duration but at air temperatures of about $0^{\circ} \mathrm{C}$, with analytical results based on Equations (9) and (7I). This comparison is shown in Figure 24. On the basis of these data Shmatkov concluded that at air temperatures of about $0^{\circ} \mathrm{C}$ the deformations are mainly caused by shearing forces.

$r(m)$

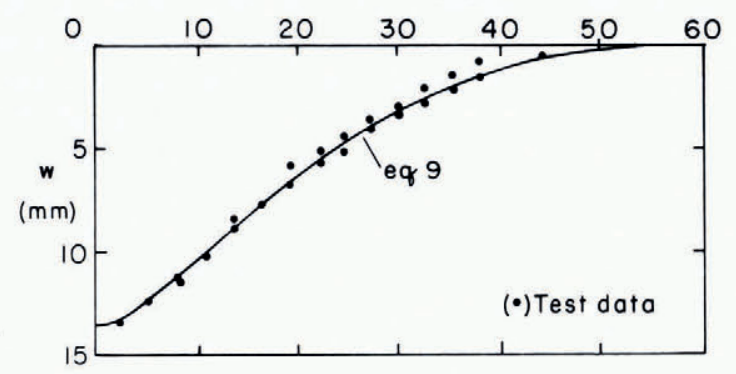

Fig. 23. Comparison of ice-plate deflections due to loads of short duration at $-1.5 \mathrm{C}<T<-7^{\circ} \mathrm{C}$.

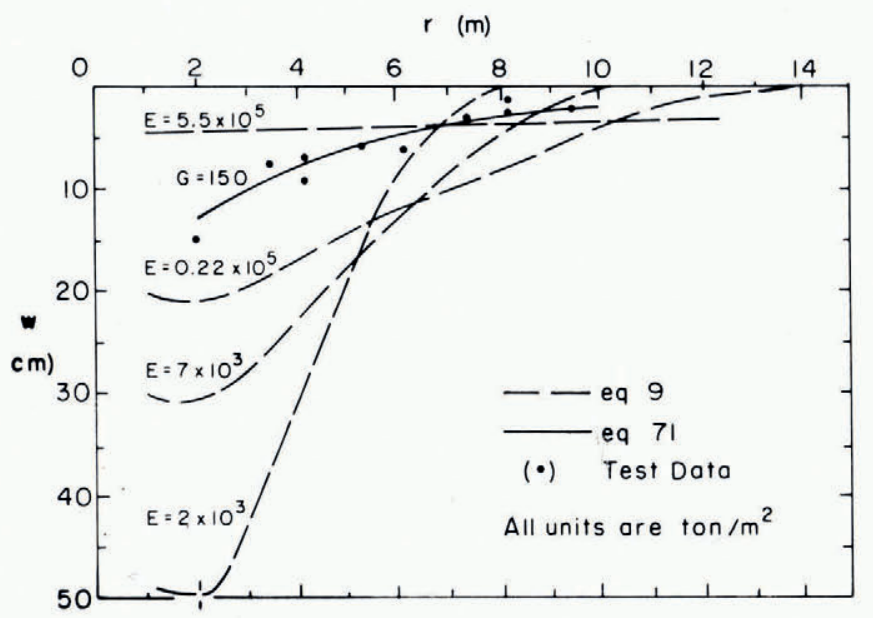

Fig. 24. Comparison of ice-plate deflections due to loads of short duration at $o^{\circ} \mathrm{C}$.

This conclusion raises the question of the effect of the ice temperature upon the range of validity of Equations (9) and (7I) for the formulation of ice covers. A comparative study involving more test data, especially at air temperatures near $0^{\circ} \mathrm{C}$, is urgently needed to clarify this important question. In these tests, a special effort should be made to separate the elastic from the non-elastic deformations. It may also be advisable to note the difference between the crystallographic structure of an ice cover formed over a lake in which the water is essentially at rest, and that over a river in which the water moves at a certain velocity, and the effect of this difference upon the mechanical properties of an ice cover. 
Determination of $P_{\mathrm{f}}(\mathrm{o})$

Test results and their relationship to the allowable load given by the analogy method were discussed by Klyucharev and Izyumov (1943) and by Kobeko and others (1946[b]). Gold (1960) compared Equation (4) with the field results of the Canadian pulp and paper industry. The conclusion from this comparison was that the formula given in Equation (4) is not sufficient for the determination of failure loads, since the presence of cracks, thermal stresses, and natural variation in effective thickness is not taken into consideration. Another reason could be that the failure load $P_{\mathrm{f}}$ is not proportional to $h^{2}$ but may be a more complicated function of $h$, as indicated by the expressions in Equations (10a) and (12a). Additional results were presented recently by Gold (I971).

In order to establish which of the various formulas for $P_{\mathrm{er}}$ and $P_{\mathrm{f}}(\mathrm{o})$ obtained using the criterion $\sigma_{\max }=\sigma_{\mathrm{f}}$ are suitable for predicting the carrying capacity of a floating plate subjected to loads of short duration, the values of $P_{\mathrm{f}}(\mathrm{o})$ obtained analytically are next compared with corresponding results from tests conducted on floating ice plates.

Since the analyses are based on an elastic theory, only the results of tests with very short loading times to failure are of interest. Such tests were recently conducted by Panfilov $(1960[a])$ in the laboratory as well as in the field. The laboratory tests were conducted at $-10^{\circ} \mathrm{C}$. The floating plate was loaded by means of stamps of the dimensions shown in Figure 25. The loads were placed statically at rates which caused breakthrough within 5 to $20 \mathrm{~s}$. Hence the loads were of short duration. In addition to the failure loads $P_{\mathrm{f}}$, loads at which the first radial crack occurred $P_{\text {cr }}$ were recorded. The laboratory tests were conducted with fresh- and salt-water ice. The thickness of the ice plates varied from 7 to $30 \mathrm{~mm}$. The field tests were conducted on thicker ice plates. An ice plate was loaded by placing a metal water tank on a structure which rested on the ice plate and simulated the contours of wheel loads. The ice strength $\sigma_{\mathrm{f}}$ was determined from floating cantilever tests with the load acting downwards. Additional details are contained in the paper by Panfilov ( $1960[a])$.

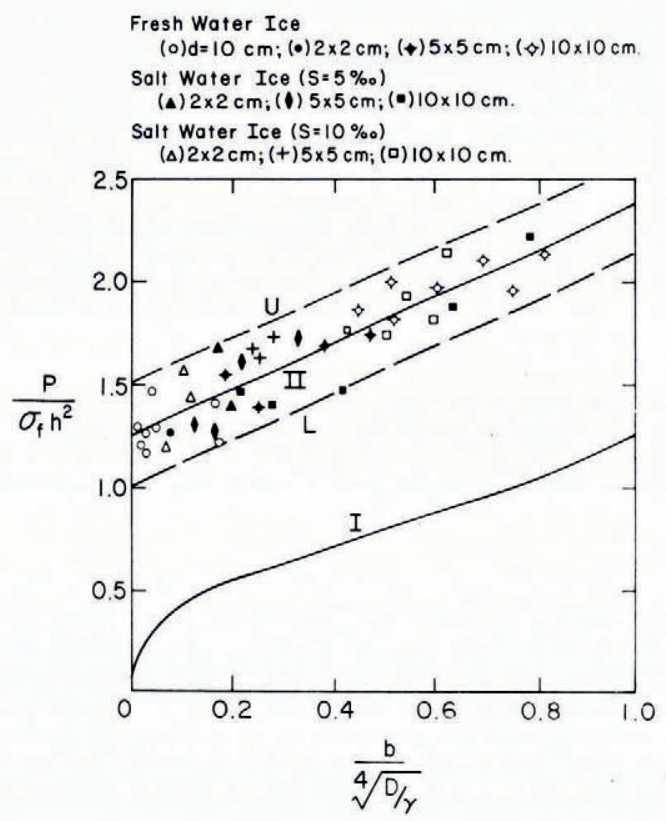

Fig. 25. Results of laboratory tests for the failure of an infinite plate. 
The results of 56 laboratory tests for the "infinite" plate are shown in Figure 25. The failures followed the usual pattern: First, the formation of radial cracks which emanated from the region under the load, then the formation of circumferential cracks at which time the load broke through the plate.

In Figure 25, Curve I represents $P_{\mathrm{cr}} /\left(\sigma_{\mathrm{f}} h^{2}\right)$ according to the analyses by Bernshteyn (1 929 ), Golushkevich in his dissertation in 1944, and Wyman (1950). Curve II was proposed by Panfilov as representing the test data and is described by the equation

$$
\frac{P}{\sigma_{\mathrm{f}} h^{2}}=\mathrm{I} .25+\mathrm{I} .05 \frac{b}{l} \text {. }
$$

It was obtained by an averaging process. The test data show a scatter in a relatively narrow band.

Before proceeding with the discussion of these test results, a different concept is introduced for the evaluation of ice-plate tests. This is necessary because averaging curves, such as curve II, are not suitable for most engineering purposes.

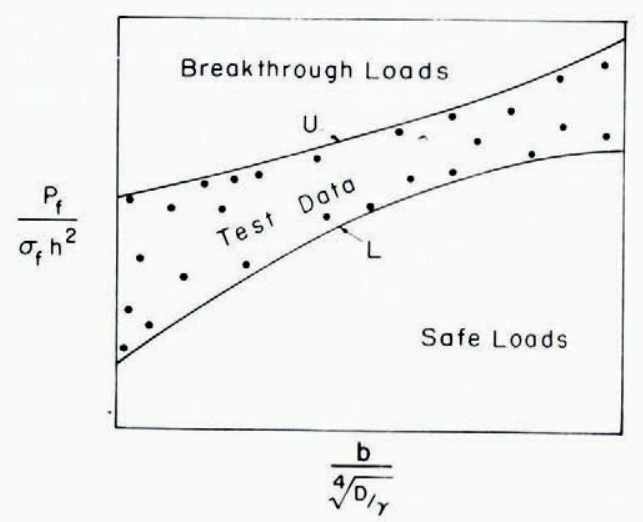

Fig. 26. Plot indicating areas of safe loads and breakthrough loads.

From an engineering point of view, there is a need to determine safe loads at which an object may move slowly or park briefly on a floating ice plate, or breakthrough loads for the design of ice breakers at which the plate definitely collapses. These loads may be obtained by introducing into the results of field tests an upper envelope $\mathrm{U}$ and a lower envelope $\mathrm{L}$, as shown in Figure 26. It is reasonable to expect that the area under envelope L contains safe loads and the area above envelope $\mathrm{u}$ the breakthrough loads. The area between the envelopes is the region of the test failure loads and nothing definite can be said about it with respect to safety or breakthrough. From this point of view, only the regions above curve $U$ and below curve $\mathrm{L}$ are of interest and the test results are needed to separate these two regions.

For the test data of infinite plates shown in Figure 25, the upper envelope $\mathrm{U}$ may be represented by the equation

$$
\left(\frac{P_{\mathrm{f}}}{\sigma_{\mathrm{f}} h^{2}}\right)_{\mathrm{C}}=\mathrm{I} \cdot 5+\mathrm{I} \cdot \mathrm{I} \frac{b}{l}
$$

and the lower envelope $\mathrm{L}$. by the equation

$$
\left(\frac{P_{\mathrm{f}}}{\sigma_{\mathrm{P}} h^{2}}\right)_{\mathrm{L}}=\mathrm{I} .0+\mathrm{I} .2 \frac{b}{l} .
$$


Therefore, if the bounds shown in Figure 25 should prove reproducible by other investigators (for loads of short duration and $T=-10^{\circ} \mathrm{C}$ ) a safe load could be determined from the condition

$$
P<\left(\mathrm{I} .0+\mathrm{I} .2 \frac{b}{(D / \gamma)^{\frac{1}{2}}}\right) \sigma_{\mathrm{p}} h^{2}
$$

where $\sigma_{\mathrm{f}}$ is obtained from a floating cantilever beam test loaded downward.

According to test data shown in Figure 25

$$
\left(P_{\mathrm{f}}^{\text {test }}\right)_{\mathrm{L}} \approx{ }_{2} P_{\mathrm{cr}} \text {. }
$$

Note, however, that the $\sigma_{\mathrm{f}}$ values for these two cases are usually not the same. Panfilov ( $1960[a])$ observed that if $P_{\text {cr }}$ is the load at which the first crack takes place then

$$
P_{\text {cr }}{ }^{\text {test }} \approx \frac{2}{3} P_{\mathrm{p}}^{\text {test }} \text {. }
$$

From the above two equations it then follows that

$$
P_{\text {cr }} \text { test } \approx \frac{4}{3} P_{\text {cr. }} \text {. }
$$

A proper analysis should yield a value of $P_{\text {cr }}$ equal to $P_{\text {cr }}{ }^{\text {test }}$. Possible reasons why this is not so in Equation (76) are: (I) The $\sigma_{\mathrm{f}}$ values used in Figure 25 are those obtained by loading the cantilever beam downward, whereas for the determination of $P_{\mathrm{cr}}$ the tensile stresses that crack the plate are in the lower fibers of the plate and there $\sigma_{\mathrm{f}}$ is smaller because of the higher temperatures; (2) The stress distribution is not linear across the plate thickness and the stresses in the upper fibers are larger than those in the bottom fibers, whereas the analyses and test evaluation are based on a linear distribution with equal stresses at the top and bottom fibers; and ( 3 ) the criterion $\sigma_{\max }=\sigma_{\mathrm{f}}$ may not be valid.

According to the simple analytical results by Kashtelyan ( 1960 ) for an infinite plate that cracks into five wedges $\left(\sigma_{n}=2 \pi / 5\right)$

$$
\frac{P_{\mathrm{f}}}{\sigma_{\mathrm{f}} h^{2}}=2.08 \frac{\phi_{n}}{\pi} \approx 0.8
$$

and when the plate cracks into six wedges $\left(\phi_{n}=\pi / 3\right)$

$$
\frac{P_{\mathrm{f}}}{\sigma_{\mathrm{f}} h^{2}} \approx 0.7 \text {. }
$$

Thus according to this analysis, $P_{\mathrm{f}}$ values are obtained which are far below the test data presented in Figure 25.

Also compare the graphs presented in Figure 20 with the test data of Figure 25. Note that the upper graphs in Figure 20 are based on $M_{0}=\sigma_{0} h^{2} / 4$ and that they may be shifted toward the test data by choosing a larger number in the denominator of $M_{0}$.

The test results for a semi-infinite plate subjected to an edge load, as shown in Figure 6 are presented in Figure 27. The failures followed the usual pattern: first, the formation of a crack, which emanates under the load and is normal to the free boundary; then the formation of a circumferential crack at which the two wedges break off.

In Figure 27, Curve I is the $P_{\text {cr }}$ according to the analyses of Shapiro (1943) and Golushkevich in his dissertation. Curve II was proposed by Panfilov (I96o[a]) as representing the test data, which show a scatter in a relatively narrow band. It is described by the equation

$$
\frac{P}{\sigma_{\mathrm{f}} h^{2}}=0.45+0.38 \frac{b}{l} \text {. }
$$

It can be easily verified that the upper envelope $\mathrm{U}$ is described by the equation

$$
\left(\frac{P}{\sigma_{\mathrm{P}} h^{2}}\right)_{\mathrm{U}}=0.5^{8}+0.27 \frac{b}{l}
$$




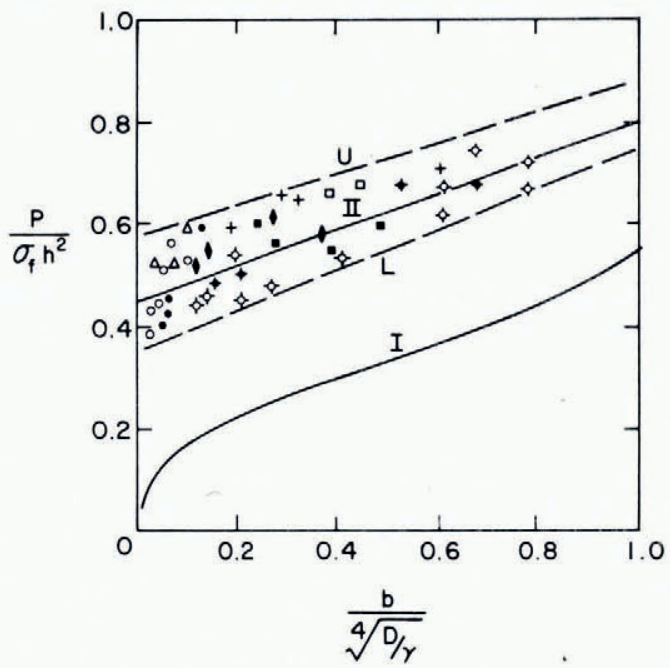

Fig. 27. Test results for the failure of a semi-infinite plate with an edge load.

and the lower envelope $\mathrm{L}$ by the equation

$$
\left(\frac{P}{\sigma_{\mathrm{P}} h^{2}}\right)_{\mathrm{L}}=0.35+0.39 \frac{b}{l} \text {. }
$$

Hence, if the bounds shown in Figure 27 should prove to be reproducible by other investigators, a safe load for the crossing of a long gap in a floating plate (a bridge between two semi-infinite plates) could be determined from the condition

$$
P<\left(0.35+0.39 \frac{b}{(D / \gamma)^{\frac{1}{2}}}\right) h^{2} \sigma_{\mathrm{f}} .
$$

On the other hand, the breakthrough load for a semi-infinite plate, often needed for the design of icebreakers, should satisfy the condition

$$
P>\left(0.5^{8}+0.27 \frac{b}{(D / \gamma)^{\frac{1}{2}}}\right) h^{2} \sigma_{\mathrm{f}}
$$

where $\sigma_{\mathrm{f}}$ is determined from a floating cantilever test loaded downward.

According to the test data shown in Figure 27, for 0.1 $<b \mid l<1$.0

$$
\left(P_{\mathrm{f}}{ }^{\text {est }}\right)_{\mathrm{L}} \approx \mathrm{I} .6 P_{\mathrm{cr}} .
$$

Panfilov ( $1960[a])$ observed that also for the semi-infinite plate

$$
P_{\text {cr }}^{\text {test }} \approx \frac{2}{3} P_{\mathrm{f}}^{\text {test }} \text {. }
$$

From the above two equations it then follows that

$$
P_{\mathrm{f}}^{\text {test }} \approx \mathrm{I} \text {. I } P_{\text {cr. }} \text {. }
$$

In view of the three possible shortcomings listed in the discussion of the infinite plate, this agreement is very close.

Panfilov's test results for the infinite and semi-infinite plate show that

$$
\left.\left(P_{\mathrm{f}}^{\text {test }}\right)_{\text {inf plate }} \approx 2.7\left(P_{\mathrm{f}}^{\text {test }}\right)\right)_{\text {semi-inf plate }}
$$

This does not agree with the findings reported by Kashtelyan (196o, p. 33). Equation (8o) indicates that the effect of the wedge-in moments is not negligible if one attempts to 
compute $P_{\mathrm{f}}$ analytically from wedge solutions. Without the wedge-in moments, $P_{\mathrm{f}}$ of the infinite plate would be equal to twice the $P_{\mathrm{f}}$ of the semi-infinite plate. In this connection, note the corresponding relationship obtained analytically for $P_{\mathrm{cr}}$, which is shown in Figure 8 .

According to Kashtelyan (1960), for the observed wedge formation for a semi-infinite plate $\phi=\pi / 2$, and

$$
P_{\mathrm{cr}} /\left(\sigma_{\mathrm{f}} h^{2}\right)=0.5^{\mathrm{I}} 8
$$

a value which agrees with the test data shown in Figure 27 for $\alpha<0.4$.

Other test data for loads of short duration were obtained by Yakunin (1970); however, these results were not available for review.

\section{Determination of $P_{\mathrm{f}}\left(t_{\mathrm{f}}\right)$}

Early test results for ice covers subjected to loads of long duration were reported by Bernshteyn (1929), the South Manchurian Railway Company (see the footnote on p. 248), Kobeko and others (1946[a], [b]) and the U.S. Corps of Engineers (1947). More recent test results are presented by Sundberg-Falkenmark (1963), Frankenstein (1968), Panfilov (1961, 1965, 1970[b]), Stevens and Tizzard (1969), and Yakunin (1970).

Although some writers compared their test data with analytical results and found satisfactory agreement for certain situations, there is a need for a systematic study of available test data, supplemented with new test results, in order to establish first the proper plate theory for ice covers which will predict the deflections as a function of time, and then a failure criterion for the determination of $P_{\mathrm{f}}\left(t_{\mathrm{f}}\right)$ and $t_{\mathrm{f}}$.

In connection with the above studies it may also be useful to note the test results presented by Shishov (1947), Butyagin (1955), Black (1958), Gold and others (1958), Korzhavin and Butyagin (196r), Frankenstein (1963), Brunk (unpublished), as well as the discussions by Assur ([1962][a]), Pister (1965), Dykins (unpublished), F.K. (1968), and Yakunin (1970).

\section{Determination of $\sigma_{\mathrm{f}}$}

For the analytical determination of $P_{\mathrm{f}}(\mathrm{o})$ the value $\sigma_{\mathrm{f}}$ is needed. It is usually determined from a beam cut out from an ice plate and tested in situ. A detailed description of such tests was given by Butyagin (1966, section IV). A cantilever test beam is shown in Figure 28 .

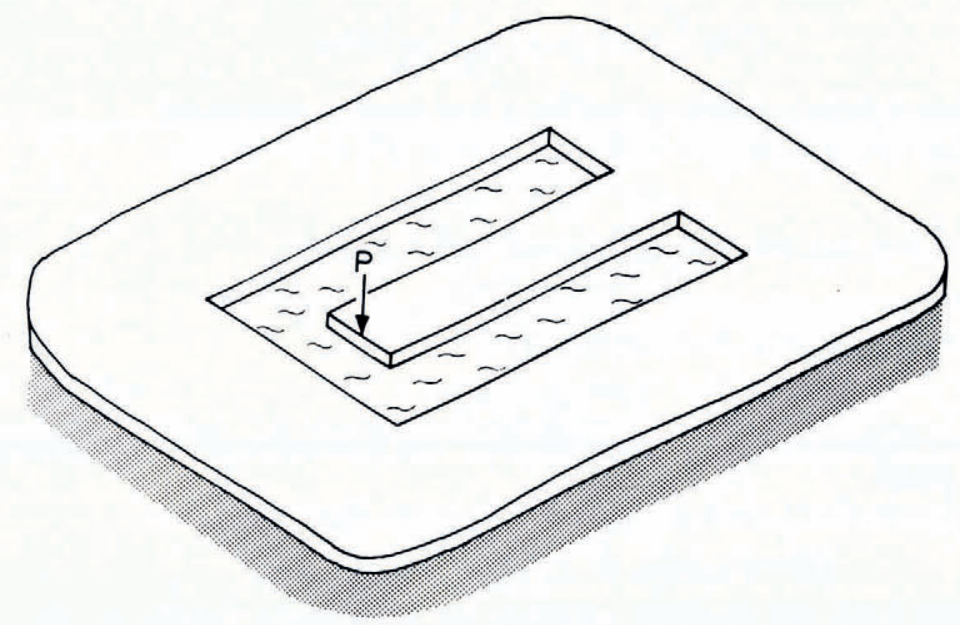

Fig. 28. Cantilever test beam for the determination of $\sigma_{\mathrm{f}}$. 
Other test data were presented by Weeks and Anderson (1958), Frankenstein (1959, 1961), Brown ( 1963 ), Sokolnikov ( 1964 ), Tabata and others ( 1967 ), and Tauriainen (1970). Related questions are discussed by Lavrov (1965, r969), Savel'yev (1963, section 5), Peschanskiy (1945), Smirnov (1967), Frankenstein (1970), Butyagin (1958), Weeks and Assur (1969), and Kerr and Palmer (1972).

In order to establish a standard procedure for the determination of $\sigma_{\mathfrak{f}}$, it should be of interest to determine the effect of the rate upon $\sigma_{\mathrm{f}}$, as well as to clarify why Frankenstein (1959, I96I), using the test set-up shown in Figure 28, found that for certain cases the determined $\sigma_{\mathrm{f}}$ value is higher when $P$ acts upwards, whereas Butyagin (1955), using the same set-up, reports that according to his test results the $\sigma_{\mathrm{f}}$ value is higher when $P$ acts downwards.

\section{SUMMARY AND RECOMMENDATIONS}

When utilizing floating ice as a place for storage purposes or as a pavement for moving vehicles, there is a need to know the magnitude of the "break-through load" $P_{\mathrm{f}}\left(t_{\mathrm{f}}\right)$ and the corresponding "time to failure" $t_{\mathrm{f}}$. Until now, there has been no general theory in the literature suitable for the prediction of $P_{\mathrm{f}}\left(t_{\mathrm{f}}\right)$. The majority of papers on the bearing capacity of ice plates deal with the determination of the special case of $P_{\mathrm{f}}(\mathrm{o})$, the load which is just sufficient to break through the ice immediately after it is placed on the ice cover. Only a few papers deal with the determination of $P_{\mathrm{f}}\left(t_{\mathrm{f}}\right)$. The procedures for the determination of $P_{\mathrm{f}}(\mathrm{o})$ and $P_{\mathrm{f}}\left(t_{\mathrm{f}}\right)$ are summarized in Table III.

Table III. Procedures for determining $P_{\mathrm{f}}(\mathrm{o})$ and $P_{\mathrm{f}}\left(t_{\mathrm{f}}\right)$

\begin{tabular}{|c|c|c|c|c|c|}
\hline \multirow[b]{3}{*}{$\begin{array}{l}\text { Analogy method } \\
\text { for deter- } \\
\text { mination of } \\
P_{\mathrm{a}}\end{array}$} & \multicolumn{2}{|r|}{$P_{\mathrm{f}}(\mathrm{o})$} & & & \multirow[t]{2}{*}{$P_{\mathrm{f}}\left(t_{\mathrm{f}}\right)$} \\
\hline & \multicolumn{2}{|c|}{ Based on elasticity analyses } & \multicolumn{2}{|c|}{ Based on plasticity analyses } & \\
\hline & $\begin{array}{l}\text { Determination } \\
\text { of } P_{\mathrm{cr}} \text { based } \\
\text { on elastic } \\
\text { theory of } \\
\text { plates and } \\
\text { criterion }\end{array}$ & $\begin{array}{l}\text { Direct deter- } \\
\text { mination of } \\
P_{\mathrm{f}}(\mathrm{o}) \text { by } \\
\text { analyzing } \\
\text { the cracked } \\
\text { plate. Use of }\end{array}$ & $\begin{array}{l}\text { Determination } \\
\text { of } P_{\mathrm{f}}(\mathrm{o}) \text { using } \\
\text { vield-line } \\
\text { theory }\end{array}$ & $\begin{array}{l}\text { Determination } \\
\text { of } P_{\mathrm{f}}(\mathrm{o}) \text { using } \\
\text { limit-load } \\
\text { theory }\end{array}$ & $\begin{array}{l}\text { Use of a visco- } \\
\text { elastic theory } \\
\text { in con- } \\
\text { junction with } \\
\text { a failure } \\
\text { criterion }\end{array}$ \\
\hline & $\begin{array}{l}\sigma_{\max }=\sigma_{\mathrm{f}} . \\
\text { Then } \\
\text { correlation of } \\
P_{\mathrm{cr}} \text { and } P_{\mathrm{f}}(\mathrm{o})\end{array}$ & $\begin{array}{l}\text { elastic theory } \\
\text { and criterion } \\
\sigma_{\max }=\sigma_{\mathrm{f}}\end{array}$ & & & ciाcin \\
\hline
\end{tabular}

Attempts to determine $P_{\mathrm{f}}(\mathrm{o})$ are based on elastic as well as plasticity theories.

The basis of the analogy method, which utilizes relationships of an elastic theory, are questionable. Thus, the results obtained with this method, although very simple, should be used with caution. In this connection, note the position of Equation (7) in Figure 25 as compared with some findings by Gold (1960, r97 I).

Another approach is based on the elastic theory of plates. In this procedure, for the given load, the maximum stress in the plate $\sigma_{\max }$ is determined first, then Equation (8), $\sigma_{\max }=\sigma_{\mathrm{f}}$, is used to determine $P_{\text {cr }}$; a load which is just sufficient to cause the first crack. Since, according to field tests, for infinite and semi-infinite plates $P_{\mathrm{f}}(\mathrm{o})>P_{\mathrm{cr}}$, an empirical relation between $P_{\mathrm{cr}}$ and $P_{\mathrm{f}}(\mathrm{o})$ is needed for the determination of $P_{\mathrm{f}}(\mathrm{o})$. Equation (74), which is based on data by Panfilov (196o[a]), could be used, if proven to be generally valid, as such an empirical relation for the infinite plate. In this procedure, $\sigma_{\mathrm{f}}$ is determined from a floating ice beam that fails in tension in the bottom region of the cross section.

In still another approach, the empirical relation is eliminated and $P_{\mathrm{f}}(\mathrm{o})$ is determined directly, by using the elastic theory for the analysis of the cracked ice plate, which consists of wedges that emanate from the loaded region, and by assuming that $P_{\mathrm{f}}(\mathrm{o})$ is reached when the wedges 
break off. Also here Equation (8) is utilized as the crack criterion. The value for $\sigma_{\mathrm{f}}$ is obtained from a floating ice beam that fails in tension in the upper region of the cross-section.

Publications that follow either of these two approaches contain several questionable assumptions; for example, although in a floating ice plate the material parameters, especially $E$, vary throughout the thickness, the expression valid for only a linear distribution of bending stresses is used exclusively for the determination of the maximum stress. Also, the use of the equation

$$
\sigma_{\mathrm{f}}=6 M_{\mathrm{f}} / h^{2}
$$

for the determination of $\sigma_{\mathrm{f}}$ from a beam test may not be justified (Kerr and Palmer, 1972).

Another questionable practice is the utilization of Equation (8) as the failure criterion. Equation (8) represents the well-known "maximum-stress criterion" (Timoshenko, 194I; Filonenko-Borodich, 196I). It implies that the failure stress $\sigma_{f}$ is not affected by any other stresses at the point of failure. Tests have shown that Equation (8) is applicable to a variety of brittle materials when not subjected to hydrostatic compression. Although many publications dealing with the bearing capacity of floating ice plates use Equation (8), not a single publication could be located which describes test results that prove, or disprove, the validity of this criterion for floating ice plates. This situation is very unsatisfactory, since $\sigma_{\max }$ in plates is usually biaxial, whereas the $\sigma_{\mathrm{f}}$ value is determined from a test with uniaxial bending stresses. Recently, Panfilov (1970[c]) suggested the criterion

$$
\sigma_{\mathrm{I}}-\mu \sigma_{2} \leqslant \sigma_{\mathrm{f}}
$$

which is the two-dimensional version of the well-known "maximum strain" criterion. However, Panfilov, did not offer sufficient experimental data to justify the use of this criterion either. In the literature on the mechanics of materials, several other failure criteria are described that may or may not be suitable for floating ice plates. For an early discussion related to plates on a Winkler base refer to Schleicher (1926, section 9). It appears that first it has to be established whether the simple criterion given by Equation (8), which is also applicable for materials with different $\sigma_{\mathrm{f}}$ values for tension and compression, is valid for floating ice plates subjected to vertical and in-plane loads.

An additional short-coming of the publications that analyze the cracked plate is that the investigators neglect the wedge-in moments in the radial cracks. This does not seem to be permissible, in view of the tests by Panfilov ( $1960[\mathrm{a}]$ ). who found that $P_{\mathrm{f}}(\mathrm{o})$ of an infinite plate is larger than $2 P_{\mathrm{f}}(0)$ for a semi-infinite plate.

The approaches for the determination of $P_{\mathrm{f}}(\mathrm{o})$ that are based on plasticity theories use the yield-line or limit-load analysis. For a discussion of a possible short-coming of these two analyses refer to the listed references. Note that the yield-line theory is conceptually related to the approach which analyzes the cracked plate. In this connection, it may be more realistic to work with cracks instead of yield lines and wedge-in moments instead of plastic moments, especially along the radial cracks.

In view of the variations of ice properties in an actual ice cover and its effect upon $P_{\mathrm{f}}(\mathrm{o})$, it may be advisable from a practical point of view to use the concept presented in Figure 26 . Its theoretical justification is that the straight-line upper or lower bounds of $P_{\mathrm{f}}(\mathrm{o})$ are of the form

$$
\frac{P_{\mathrm{f}}}{\sigma_{\mathrm{f}} h^{2}}=A+B \alpha
$$

which relates it to various analyses discussed above. This approach, if restricted to straightline bounds, is essentially the same as the one discussed by Papkovich (1962, p. 424-26), except for the introduction of the notion of upper and lower bounds for $P_{\mathrm{f}}(\mathrm{o})$. Also, note the similarity of the trend of the graphs and test data shown in Figures 4, 20 and 25 . 
The experimental data for $P_{\mathrm{f}}(\mathrm{o})$ presented by Panfilov (Ig6o[a]) (Fig. 25 and Fig. 27) show little scatter. More test data are needed to establish whether the $P_{\mathrm{f}}$ values for other ice plates, tested under different conditions, fall in the same range.

The analytical determination of $P_{\mathrm{f}}(t)$ has received much less attention than the determination of $P_{\mathrm{f}}(\mathrm{o})$. It is reasonable to assume that the necessary formulation consists of a visco-elastic plate theory and a failure criterion. In this connection, it is essential first to establish the range of validity of a simple formulation consisting of a linear visco-elastic plate theory (a bending theory, a shear theory, or a combination of both effects) in conjunction with a failure criterion of the type shown in Equation (58).

Until reliable analytical methods are developed for predicting $P_{\mathrm{f}}\left(t_{\mathrm{f}}\right)$ and $t_{\mathrm{f}}$, from a praçtical point of view it appears advisable to establish whether the empirical relation, Equation (62), or a similar expression, as proposed by Assur $([1962][\mathrm{b}])$, is generally valid. The test results needed for this purpose are also necessary for formulating the proper failure criterion as well as for establishing the validity of a chosen visco-elastic plate theory.

\section{MS. received 27 November 1972 and in final form 18 December 1975}

\section{REFERENGES}

Assur, A. 1956. Airfields on floating ice sheets for regular and emergency operations. U.S. Snow, Ice and Permafrost Research Establishment. Technical Report 36.

Assur, A. [1962][a]. Surfacing submarines through ice. Proceedings of the 1962 Army Science Conference, U.S. Military Academy, West Point, N.Y., 20-22 June 1962. Washington, D.C., [Ü.S.] Army Research Office, Vol. I, p. I I-20.

Assur, A. [1962][b]. Traffic over frozen or crusted surfaces. (In Meccanica dei sistemi suolo-veicolo. Atti del I Convegno Internazionale del Movimento fuori strada, Torino-Saint Vincent, 12-16 Giugno 1961. Torino, Edizioni Minerva Tecnica, p. $9^{1} 3^{-23}$.)

Assur, A. 1967. Flexural and other properties of sea ice sheets. (In Oura, H., ed. Physics of snow and ice: international conference on low temperature science. ... 1966. ... Proceedings, Vol. I, Pt. I. [Sapporo], Institute of Low Temperature Science, Hokkaido University, p. 557-67.)

Banin, A. P. 1960. Osnovy tekhniki bezopasnosti pri rabotakh so l'da [Safety fundamentals when working on ice covers]. Stroitel'stvo Truboprovodov, No. 3, p. 16-19.

Bernell, L. 1952. Brottförloppet i statiskt armerade betongbeläggningar. Betong, Vol. 37, Nr. 2, p. $119-45$.

Bernshteyn, S. 1929. Ledyanaya zheleznodorozhnaya pereprava [The railway ice crossing]. Trudy NauchnoTekhnicheskogo Komiteta Narodnogo Komissariata Putei Soobshcheniya, Tom 84, p. 36-82.

Black, L. D. 1958. Relative strength of plates on elastic foundation. Transactions of the Engineering Institute of Canada, Vol. 2, No. 3, p. 1 29-31.

Bogorodskiy, V. V., and others. I971. Fizika presnovodnogo l'da [The physics of fresh water ice]. [By] V. V. Bogorodskiy, A. V. Gusev, G. P. Khohklov. Leningrad, Gidrometeorologicheskoye Izdatel'stvo.

Bregman, G. R., and Proskuryakov, B. V., ed. 1943. Ledyanyye perepravy [Ice crossings]. Trudy NauchnoIssledovatel'skikh Uchreshdenii, Ser. 4, Vyp. 5.

Isrown, J. H. I963. Elasticity and strength of sea ice. (In Kingery, W. D., ed. Ice and snow; properties, processes, and applications: proceedings of a conference held at the Massachusetts Institute of Technology, February 12-16, 1962. Cambridge, Mass., M.I.T. Press, p. 79-106.)

Brunk, H. Unpublished. Über die Tragfähigkeit von Eisdecken. [Dr.Ing. thesis, Technische Hochschule Braunschweig, 1964.]

Butyagin, I. P. 1955. Issledovaniye prochnosti ledyanogo pokrova r. Obi v vesenniy period [The investigation of strength of the ice cover of the river Ob' during the spring season]. Meteorologiya $i$ Gidrologiya, 1955, No. 3, p. $42-44$.

Butyagin, I. P. I958. O prochnosti ledyanogo pokrova pri srezyvayushchikh usiliyakh [On the strength of an ice cover subjected to shearing forces]. Akademiya Nauk SSSR. Zapadno-Sibirskiy Filial. Trudy TransportnoEnergeticheskogo Instituta, Vyp. 7, p. 47-57.

Butyagin, I. P. 1966. Prochnost' l'da i ledyanogo pokrova (naturnyye issledovaniya na rekakh Sibiri) [The strength of ice and of floating ice (experiments on Siberian rivers) ]. Novosibirsk, Izdatel'stvo "Nauka".

Chikovskiy, S. S. 1965. Opredeleniye gruzopod"yemnosti ledyanogo pripaya v rayone Mirnogo [Determination of the load-bearing capacity of the fast ice in the Mirny region]. Informatsionnyy Byulleten' Sovetskoy Antarkticheskoy Ekspeditsii, No. 55, p. 23-27.

Coon, M. D., and Mohaghegh, M. M. 1972. Plastic analysis of Coulomb plates and its application to the bearing capacity of sea ice. Seattle, University of Washington. (Report on Office of Naval Research Grant Nooor4-67-A-01030007 , Project No. NR 307-252.)

Cutcliffe, J. L., and others. I963. Elastic and time-dependent deformation of ice sheets, by J. L. Cutcliffe, W. D. Kingery and R. L. Coble. (In Kingery, W. D., ed. Ice and snow; properties, processes, and applications: proceedings of a conference held at the Massachusetts Institute of Technology, February 12-16, 1962. Cambridge, Mass., M.I.T. Press, p. 305-10.) 
Daily, A. F. 1969. Off-the-ice placer prospecting for gold. (In First Annual Offshore Technology Conference, May 18-21, 1969, Houston, Texas. [Preprint], Vol. I, p. I-277-I-284.)

Dieudonné, J. Unpublished. Study of the equation $\frac{\mathrm{d}^{4} y}{\mathrm{~d} x}+\frac{2}{x} \frac{\mathrm{d}^{3} y}{\mathrm{~d} x^{3}}+y=0$ for $x \geqq 0$. [Written 1957. Results reproduced in Nevel, D. E. 1968. General solution of a wedge on an elastic foundation. U.S. Cold Regions Research and Engineering Laboratory. Research Report 247.]

Duff, C. H. 1958. Ice landings. Transactions of the Engineering Institute of Canada, Vol. 2, No. 3, p. 99-100.

Dykins, J. E. Unpublished. Review of sea ice sheet loading. [Undated account, available from author, U.S. Naval Civil Engineering Laboratory, Port Hueneme, California.]

F.K. I 68 . Nośność powlok lodowych na jeziorach [The bearing capacity of ice covers on lakes]. Drogownictwo, Vol. 23, No. 9, p. 223-26.

Filonenko-Borodich, M. M. 1961. Mekhanicheskiye teorii prochnosti [Mechanical theories of failure]. Moscow, Izdatel'stvo Moskovskogo Universiteta.

Frankenstein, G. E. 1959. Strength data on lake ice. U.S. Snow, Ice and Permafrost Research Establishment. Technical Report 59 .

Frankenstein, G. E. 1961. Strength data on lake ice II. U.S. Snow, Ice and Permafrost Research Establishment. Technical Report 8 o.

Frankenstein, G. E. 1963. Load test data for lake ice sheets. U.S. Cold Regions Research and Engineering Laboratory. Technical Report 89 .

Frankenstein, G. E. 1968. Strength of ice sheets. Canada. National Research Council. Associate Committee on Geotechnical Research. Technical Memorandum No. 92, p. 79-87.

Frankenstein, G. E. 1970. The flexural strength of sea ice as determined from salinity and temperature profiles. Canada. National Research Council. Associate Committee on Geotechnical Research. Technical Memorandum No. 98, p. 66-73.

Freudenthal, A. M., and Geiringer, H. 1958. The mathematical theories of the inelastic continuum. (In Flügge, S., ed. Encyclopedia of physics. Vol. 6. Berlin, Springer-Verlag, p. 229-432.)

Garbaccio, D. H. 1967. Creep of floating ice sheets. Science Engineering Associates Report No. CR-67-025.

Garbaccio, D. H. 1968. Creep of floating ice sheets: computer calculations. Science Engineering Associates Report No. CR-69-o I 4 .

Gold, L. W. rg6o. Field study on the load bearing capacity of ice covers. Woodland Review (Pulp and Paper Magazine of Canada), Vol. 6i, No. 5, p. $153-54,156-58$.

Gold, L. W. 197 I. Use of ice covers for transportation. Canadian Geotechnical Journal, Vol. 8, No. 2, p. 170-81.

Gold, L. W., and others. 1958. Deflections of plates on elastic foundation, by L. W. Gold, L. D. Black, F. Trofimenkov and D. Matz. Transactions of the Engineering Institute of Canada, Vol. 2, No. 3, p. 123-28.

Gouré, L. 1964. The siege of Leningrad. New York, McGraw-Hill.

Gusev, O. V. I961. Perepravy po l'du [Crossings over ice]. Leningrad, Gidrometeorologicheskoye Izdatel'stvo.

Herbert, W. 1970. The first surface crossing of the Arctic Ocean. Geographical Journal, Vol. 1 36, Pt. 4, p. 51 1-33.

Hertz, H. 1884. Über das Gleichgewicht schwimmender elastischer Platten. Wiedemann's Annalen der Physik und Chemie, Vol. 22, p. 449-55. [English translation: "On the equilibrium of floating elastic plates", in Miscellaneous papers by H. Hertz. London, MacMillan, 1896 , p. 266-72.]

Hetényi, M. 1946. Beams on elastic foundation. Ann Arbor, University of Michigan Press.

Hopkins, H. G., and others. I961. Discussion of "Bearing capacity of floating ice sheets" by G. G. Meyerhof, by H. G. Hopkins [and 7 others]. Proceedings of the American Society of Civil Engineers. Fournal of the Engineering Mechanics Division, Vol. 87, EM 1, p. $18_{5} ; \mathrm{EM}_{2}$, p. 83-88; EM 3 , p. 63-66; EM 5 , p. 87-96; EM6, p. 161-66.

Jansson, J.-E. 1956. Ice-breakers and their design. European Shipbuilding, Vol. 5, No. 5, p. I 1 2-28; No. 6, p. $143-51$.

Johansson, A. 1947. Försök med armerade betongplattor på elastiskt underlag. Betong, Vol. 32, Nr. 3, p. 187-209.

Kashtelyan, V. I. 1960. Priblizhennoye opredeleniye usiliy, razrushayushchikh ledyanoy pokrov [An approximate determination of forces which break up a floating ice plate]. Problemy Arktiki $i$ Antarktiki, Vyp. 5, p. 31-37.

Kerr, A. D. I 959[a]. Elastic plates with simply supported straight boundaries resting on a liquid foundation. U.S. Cold Regions Research and Engineering Laboratory. Research Report 59. [Also published as Elastic plates on a liquid foundation. Proceedings of the American Society of Civil Engineers, Journal of the Engineering Mechanics Division, Vol. 89, No. EM3, r 1963 , p. 59-71.]

Kerr, A. D. 1959[b]. Plastic deformation of floating ice plates subjected to static loads. U.S. Snow, Ice and Permafrost Research Establishment. Research Report 57.

Kerr, A. D. 1964. Elastic and viscoelastic foundation models. Journal of Applied Mechanics, Vol. 31, No. 3, p. $49 \mathrm{I}-98$.

Kerr, A. D. ${ }^{1965}$. Bending of circular plates sealing an incompressible liquid. Fournal of Applied Mechanics, Vol. 32, No. 3, p. 704-06.

Kerr, A. D. 1966. On plates sealing an incompressible liquid. International Journal of Mechanical Sciences, Vol. 8, No. 4 , p. 295-304.

Kerr, A. D., and Becker, R. S. 1967. The stress analysis of circular plates sealing a compressible liquid. International fournal of Mechanical Sciences, Vol. 9, No. 10, p. 719-26.

Kerr, A. D., and Palmer, W. T. 1972. The deformations and stresses in floating ice plates. Acta Mechanica, Vol. ${ }_{5}$, Nos. 1-2, p. 57-72.

Kheysin, D. Ye. r 964 . K zadache uprugo-plasticheskogo izgiba ledyanogo pokrova [On the problem of the elastic-plastic bending of an ice cover]. Trudy Arkticheskogo i Antarkticheskogo Nauchno-Issledovatel'skogo Instituta, Tom 267 , p. $143-49$.

Klyucharev, V., and Izyumov, S. 1943. Opredeleniye gruzopod"yemnosti ledyanykh pereprav [Determination of the carrying capacity of ice crossings]. Voyenno-Inzhenernyy Zhurnal, Vol. 2-3, p. 30-34. 
Kobeko, P. P., and others. 1946[a]. Plasticheskaya deformatsiya i vyazkost' l'da [Plastic deformations and viscosity of ice]. [By] P. P. Kobeko, N. I. Shishkin, F. I. Marey, N. S. Ivanova. Zhurnal Tekhnicheskoy Fiziki, Tom ı6, No. 3 , p. $263-72$.

Kobeko, P. P., and others. 1946[b]. Prolom i gruzopod"yemnost' l'da [The break-through and carrying capacity of a floating ice cover]. [By] P. P. Kobeko, N. I. Shishkin, F. I. Marey, N. S. Ivanova. Zhurnal Tekhnicheskoy Fiziki, Tom 16 , No. 3, p. 273-76.

Korenev, B. G. 1954. Raschet balok $i$ plit lezhashchikh na uprugom osnovanii [Analysis of beams and plates on elastic foundation]. Moscow, Stroizdat.

Korenev, B. G. 1957. Konstruktsii, lezhashchiye na uprugom osnovanii [Structures on elastic foundation]. (In Rabinovich, I. M., ed. Stroitel'naya mekhanika v SSSR 1917-1957. Moscow, Gosudarstvennoye Izdatel'stvo Literatury po Stroitel'stvu i Arkhitekture, p. 115-35.)

Korenev, B. G. 196o. Nekotoryye zadachi teorii uprugosti i teploprovodnosti, resheyeniyye v Besselevykh funktsiykh [Problems in the theory of elasticity and heat transfer solvable by means of Bessel functions]. Moscow, Fizmatgiz.

Korenev, B. G. 1969 . Konstruktsii, lezhashchiye na uprugom osnovanii [Structures on elastic foundation]. (In Rabinovich, I. M., ed. Stroitel'naya mekhanika v SSSR $1917-1967$. Moscow, Stroyizdat, p. $112-34$.)

Korenev, B. G., and Chernigovskaya, E. I. 1962. Raschet plit na uprugom osnovanii [Analysis of plates on elastic foundation]. Moscow, Gosudarstvennoye Izdatel'stvo Literatury po Stroitel'stvu, Arkhitekture i Stroitel'nym Materialam.

Korunov, M. M. I939-40. Raschet ledyanykh pereprav [The calculation of ice crossings]. Avtobronetankovyy Zhurnal, Tom 9, No. 8, p. 69-79; Tom 10, No. 2, p. 58-63; Tom 10, No. 11, p. 62-67.

Korunov, M. M. 1940. Raschet ledyanykh pereprav [The calculation of ice crossings]. Moscow, Goslestekhizdat.

Korunov, M. M. I956. O gruzopod"yemnosti ledyanogo pokrova pri transportirovke lesa [Load carrying capacity of ice for timber transport]. Lesnaya Promyshlennost', Tom 34, No. 1 1, p. 18-19.

Korunov, M. M. 1967 . Priblizhennyy metod opredeleniya gruzopod"yemnosti ledyanogo pokrova [An approximate method for the determination of the bearing capacity of an ice cover]. Trudy, Sverdlovsk NauchnoIssledovatel'skiy Institut Lesnoy Promyshlennosti, Tom 3, p. 122-29.

Korunov, M. M. r968. Bezopasnost' stoyanki gruzov na ledyanom pokrove [The safety of loads of long duration resting on ice covers]. Izvestiya Vysshikh Uchebnykh Zavedeniy. Lesnoy Zhurnal, Tom 3, p. 44-46.

Korzhavin, K. N. 1962. Vozdeystviye l'da na inzhenernye sooruzheniya [Action of ice on engineering structures]. Novosibirsk, Izdatel'stvo Sibirskogo Otdel, Akademiya Nauk SSSR.

Korzhavin, K. N., and Butyagin, I. P. $196 \mathrm{I}$. Issledovaniye deformatsii i prochnosti ledyanykh poley v naturnykh uslovyakh [Determination of the deformation and strength of ice covers in their natural environment]. Akademiya Nauk SSSR. Zapadno-Sibirskiy Filial. Trudy Transportno-Energeticheskogo Instituta, Vyp. I I, p. 3-1 2.

Kovacs, A. 1972. On pressured sea ice. (In Karlsson, T., ed. Sea ice. Proceedings of an international conference. ... . Reykjavík, Iceland, May IO-13, I971. Reykjavík, National Research Council, p. 276-95.)

Krylov, Yu. M. 1948. Rasprostraneniye dlinnykh voln pod ledyanym polem [The propagation of long waves under an ice cover]. Trudy Gosudarstvennogo Okeanograficheskogo Instituta, Tom 8, No. 20, p. 107-10.

Kubo, Y. 1958. Shizen keppyōpan no taikaryoku ni tsuite [Loading capacity of ice-plate]. Seppyō, Vol. 20, No. 3 , p. I I-14; No. 4 , p. $97-104$.

Lagutin, B. L., and Shulman, A. P. 1946. O metodakh rascheta ledyanykh pereprav [Methods of calculating the load carrying capacity of an ice crossing]. Trudy Nauchno-Issledovatel'skikh Uchrezhdeniy, Ser. 5, Vyp. 20, p. 39-50.

Lavrov, V. V. 1965. Vliyaniye struktury l'da na yego prochnost' [The influence of ice structure upon its strength]. Problemy Arktiki $i$ Antarktiki, Vyp. 20, p. $6 \mathrm{I}-67$.

Lavrov, V. V. r969. Deformatsiya $i$ prochnost' l'da [Deformation and strength of ice]. Leningrad, Gidrometeorologicheskoye Izdatel'stvo. [Translation published by Israel Program for Scientific Translations, Jerusalem, 1971.]

Lebedev, P. I. 1940. Ledyanyye perepravy [Ice crossings]. Moscow, Voyenizdat.

Lewe, V. 1923. Platten rechteckiger Grundrissteilung auf elastisch nachgiebiger Unterlage. Die umgekehrte Pilzdecke als Fundament. Der Bauingenieur, Bd. 4, Ht. I 5, p. 453-55.

Linell, K. A. 1958. Use of ice as a load-supporting surface. U.S. Arctic Construction and Frost Effects Laboratory. Miscellaneous Paper 19.

Lysukhin, I. F. 1968. Inzhenernoye obespecheniye forsirovaniya rek [The engineering of river crossings]. Moscow, Voyennoye Izdatel'stvo Ministerstva Oborony SSSR.

Mahrenholtz, O. I966. Zur Tragfähigkeit von Eisdecken. Zeitschrift für angewandte Mathematik und Mechanik, Bd. 46, Sonderheft, p. Ti $70-T_{173}$.

Marchuk, A. N., and Mitta, S. V. I966. Ispol'zovaniye nesushchei sposobnosti l'da na stroitel'stve Bratskoi GES [The utilization of the bearing capacity of the ice cover during construction of the Bratsk hydro-electric power plant]. Gidrotekhnicheskoye Stroitel'stvo, No. 7, p. 29-33.

Meyerhof, G. G. 1960. Bearing capacity of floating ice sheets. Proceedings of the American Society of Civil Engineers, Fournal of the Engineering Mechanics Division, Vol. 86, EM 5, p. $1_{1} 3-45$.

Moskatov, K. A. 1938. O posadke samoletov na led [Landing of airplanes on ice]. Trudy Arkticheskogo Instituta, Tom iro, p. 43-55.

Müller, W. 1952. Zur Theorie der rechteckigen Fundamentplatten und Pilzdecken. Ingenieur-Archiv, Bd. 20, Ht. 4 , p. $278-90$.

Nevel, D. E. 1958. The theory of a narrow infinite wedge on an elastic foundation. Transactions of the Engineering Institute of Canada, Vol. 2, No. 3, p. I 32-40.

Nevel, D. E. 1961. The narrow free infinite wedge on an elastic foundation. U.S. Snow, Ice and Permafrost Research Establishment. Research Report 79. 
Nevel, D. E. ${ }^{1963}$. Circular plates on elastic sealed foundations. U.S. Cold Regions Research and Engineering Laboratory. Research Report I 18.

Nevel, D. E. 1965. A semi-infinite plate on an elastic foundation. U.S. Cold Regions Research and Engineering Laboratory. Research Report 136.

Nevel, D. E. 1966. Time dependent deflection of a floating ice sheet. U.S. Cold Regions Research and Engineering Laboratory. Research Report 196.

Nevel, D. E., and Assur, A. 1968. Crowds on ice. U.S. Cold Regions Research and Engineering Laboratory. Technical Report 204.

Newman, M., and Forray, M. 1962. Thermal stresses and deflections in thin plates with temperature dependent elastic modulus. Journal of Aerospace Sciences, Vol. 29, No. 3, p. 372-73.

Palmer, W. T. Unpublished. On the analysis of floating ice plates. [Ph.D. thesis, New York University, 1971.]

Panfilov, D. F. I $960[a]$. Experimental'nyye issledovaniya gruzopod"yemnosti ledyanogo pokrova [Experimental investigation of the carrying capacity of a floating ice plate]. Izvestiya Vsesoyuznogo Nauchno-Issledovatel'skogo Instituta Gidrotekhniki, Tom 64, p. 10 I-1 5 .

Panfilov, D. F. 1960[b]. Priblizhennyy metod rascheta gruzopod"yemnosti ledyanogo pokrova [Approximate method to analyse the bearing capacity of an ice cover]. Izvestiya Vsesoyuznogo Nauchno-Issledovatel'skogo Instituta Gidrotekhniki, Tom 65, p. $221-24$.

Panfilov, D. F. 1961. K raschetu gruzopod"'yemnosti ledyanogo pokrova pri stoyanke gruzov na l'du [On the determination of the carrying capacity of an ice cover for loads of long duration]. Izvestiya Vysshikh Uchebnykh Zavedeniy Ministerstva Vysshego $i$ Srednego Spetsial'nogo Obrazovaniya SSSR. Stroitel'stvo i Arkhitektura, 1961, 6, p. 47-57.

Panfilov, D. F. 1963[a]. Izgib neogranichennogo ledyanogo polya kratkovremennoy staticheskoy nagruzkoy [Bending of a floating infinite ice plate subjected to a static load of short duration]. Izvestiya Vysshikh Uchebnykh Zavedeniy Ministerstva Vysshego $i$ Srednego Spetsial'nogo Obrazovaniya SSSR. Stroitel'stvo i Arkhitektura, 1963, 6, p. $60-70$.

Panfilov, D. F. I963[b]. Izgib polubeskonechnogo ledyanogo polya nagruzkoy prilozhennoy $\mathrm{k}$ kromke l'da [Bending of a semi-infinite ice cover subjected to loads along the free edge]. Izvestiya Vysshikh Uchebnykh Zavedeniy Ministerstva Vysshego i Srednego Spetsial'nogo Obrazovaniya SSSR. Stroitel'stvo i Arkhitektura, 1963, No. I 1-12, p. 54-61.

Panfilov, D. F. 1963 [c]. O metodakh rascheta gruzopod"yemnosti l'da [On methods for the determination of the bearing capacity of ice covers]. Gidrotekhnicheskoye Stroitel'stvo, No. 4, p. 39-42.

Panfilov, D. F. I $_{6}$ [d]. Proverka prochnosti ledyanogo pokrova pri opuskanii truboprovodov so l'da [Strength check of an ice cover when subjected to the lowering of pipelines]. Stroitel'stvo Truboprovodov, No. 9, p. 10-12.

Panfilov, D. F. 1964[a]. Izgib ledyanogo pokrova kratkovremennoy staticheskoy nagruzkoy [Bending of an ice cover subjected to a static load of short duration]. Trudy Koordinatsionnykh Soveshchaniy po Gidrotekhnike, Vyp. Io, p. $81-103$.

Panfilov, D. F. 1964[b]. Priblizhennyye formuly dlya opredeleniya nesushchei sposobnosti l'da [Approximate formulas for the determination of the carrying capacity of ice]. Trudy Koordinatsionnykh Soveshchaniy po Gidrotekhnike, Vyp. 10, p. 104-12.

Panfilov, D. F. I 965 . O deformatsiyakh polzuchesti l'da [On creep deformations of ice]. Trudy Koordinatsionnykh Soveshchaniy po Gidrotekhnike, Vyp. 23, p. 1 $10-20$.

Panfilov, D. F. I966[a]. Izgib beskonechnoy polosy l'da pri kratkovremennom deystvii nagruzki [Bending of the infinite ice strip which is subjected to a load of short duration]. Izvestiya Vysshikh Uchebnykh Zavedeniy Ministerstva Vysshego i Srednego Spetsial'nogo Obrazovaniya SSSR. Stroitel'stvo i Arkhitektura, 1966, No. 12, p. 100-09.

Panfilov, D. F. 1966[b]. Raschet nesushchey sposobnosti ledyanogo pokrova s uchetom neodnorodnosti yego po tolshchine [Analysis of the bearing capacity of an ice cover taking into consideration its nonhomogeneity with thickness]. Izvestiya Vysshikh Uchebnykh Zavedeniy Ministerstva Vysshego i Srednego Spetsial'nogo Obrazovaniya SSSR. Stroitel'stvo i Arkhitektura, 1966, No. 2, p. 3-8.

Panfilov, D. F. I970[a]. Izgib plavayushchey polosy l'da pod deystviyem mestnoy nagruzki, prilozhennoy v blizi kromki [Bending of a floating ice strip subjected to local loads near the edge]. Izvestiya Vysshikh Uchebnykh Zavedeniy Ministerstva Vysshego i Srednego Spetsial'nogo Obrazovaniya SSSR. Stroitel'stvo i Arkhitektura, 1970, No. I, p. $144-48$.

Panfilov, D. F. 1970[b]. Izmeneniye nesushchey sposobnosti ledyanogo pokrova pri dlitel'nom prebyvanii na nem gruzov [The change of the bearing capacity of an ice cover due to loads of long duration]. Izvestiya Vysshikh Uchebnykh Zavedeniy Ministerstva Vysshego $i$ Srednego Spetsial'nogo Obrazovaniya SSSR. Stroitel'stvo i Arkhitektura, 1970, No. 3, p. 107-13.

Panfilov, D. F. I970[c]. Raschet ledyanogo pokrova na prochnost' [Calculating ice cover strength]. Izvestiya Vysshikh Uchebnykh Zavedeniy Ministerstva Vysshego i Srednego Spetsial'nogo Obrazovaniya SSSR. Stroitel'stvo $i$ Arkhitektura, 1970, No. 6, p. 129-33.

Papkovich, P. F. 1962. Trudy po stroitel'noy mekhanike korablya. Pod obshchey red. V. V. Yekimova. Tom I. Leningrad, Sudpromgiz.

Persson, B. O. E. 1948. Beständighet och bärighet hos ett istäcke. Svenska Vägföreningens Tidskrift, Vol. 35, No. 10, p. 406-17.

Peschanskiy, I. S. I945. Raspredeleniye prochnosti l'da po tolshchine i izmeneniye yeye $\mathrm{v}$ techeniye goda [The distribution of strength with respect to thickness and its variation in the course of the year]. Problemy Arktiki, 1945, No. 2.

Peschanskiy, I. S. 1967. Ledovedeniye i ledotekhnika. Izdaniye 2-ye, dopolnennoye $i$ pereabotannoye [Glaciology and ice technology. 2nd edition, augmented and revised]. Leningrad, Gidrometeorologicheskoye Izdatel'stvo.

Pickett, G., and Ray, G. K. 1951. Influence charts for concrete pavements. Transactions of the American Society of Civil Engineers, Vol. I 16 , Paper No. 2425, p. 49-73. 
Pister, K. S. 1965. Mechanical properties of sea ice with reference to structural behavior of ice sheets. U.S. Naval Civil Engineering Laboratory. Technical Note N-758.

Popov, Yu. N., and others. I967. Prochnost' sudov plavayushchikh vo l'dakh [The strength of ships which operate in ice]. [By] Yu. N. Popov, O. V. Fadeyev, D. Ye. Kheysin, A. A. Yakovlev. Leningrad, Izdatel'stvo Sudostroyeniye.

Röthlisberger, H. r 968 . Das Problem der Tragfähigkeit der Eisdecke anlässlich der Zürcher Seegfrörni, 1963. Schweizerische Bauzeitung, Jahrg. 86, Nr. 31, p. 565-69.

Rose, L. B., and Silversides, C. R. 1958. The preparation of ice landings by pulp and paper companies in eastern Canada. Transactions of the Engineering Institute of Canada, Vol. 2, No. 3, p. 101-07.

Savel'yev, B. A. 1963 . Stroyeniye, sostav $i$ svoystva ledyanogo pokrova morskikh i presnykh vodoyemov. [Structure, composition and properties of the ice cover of sea and fresh water]. Moscow, Idzatel'stvo Moskovskogo Universiteta.

Savel'yev, N. G. 1969. Obzor i bibliografiya rabot po raschetu soprikasayushchikhsiya detaley [Survey and bibliography of papers on the analysis of elements in contact]. Raschety na Prochnost', Vyp. 14, p. 76-126.

Schleicher, F. 1926. Kreisplatten auf elastischer Unterlage. Berlin, Julius Springer.

Serebryanyy, R. V. 1960. Opredeleniye razrushayushchey nagruzki dlya plit na uprugom osnovanii [Determination of the collapse load for plates on an elastic foundation]. Osnovaniya Fundamenty $i$ Mekhanika Gruntov, No. 2, p. $10-12$.

Sergeyev, B. N. 1929. Ustroistvo zimney perepravy vagonov po l'du i rabota ledyanogo sloya pod deystiyem nagruzki [Construction of winter ice crossings for railroad cars and the response of the ice cover when subjected to loads]. Trudy Nauchno-Tekhnicheskogo Komiteta Narodnogo Komissariata Putei Soobshcheniya, Tom 84, p. 5-35.

Shapiro, G. S. I 1942 . Design of a plate conceived as an infinite band resting upon elastic foundation. Comptes Rendus de l'Académie des Sciences de l'URSS, Tom. 37, Nos. 7-8, p. 202-04.

Shapiro, G. S. 1943. Izgib polubeskonechnoy plity, lezhashchei na uprugom osnovanii [Deflection of a semiinfinite plate on an elastic foundation]. Prikladnaya Matematika $i$ Mekhanika, Tom 7, No. 4, p. 316-20.

Sharp, R. P. I947. Suitability of ice for aircraft landings. Transactions. American Geophysical Union, Vol. 28, No. I, p. I I I-I 9 .

Shekhter, O. Ya., and Vinokurova, A. V. 1936. Raschet plity na uprugom osnovanii [Analysis of plates on elastic foundation]. Moscow, Glavnaya Redaktsiya Stroitel'noy Literatury.

Shishov, N. D. 1947. O prochnosti l'da [On the strength of ice]. Meteorologiya i Gidrologiya, 1947, No. 2, p. 38-41.

Shmatkov, V. A. 1968. Kharakteristika deformatsionnykh svoystv ledyanogo pokrova oz. Baykal v vesennii period [The deformation characteristics of the ice cover of lake Baykal during the spring period]. Trudy Gosudarststvennogo Gidrologicheskogo Instituta, Tom i 59, p. 29-33.

Shulman, A. R. I 946 . K raschetu gruzopod"yemnosti ledyanykh pereprav po teorii tsentral'nogo izgiba uprugoy plity na uprugom osnovanii [Calculation of the load-carrying capacity of ice crossings on the basis of the theory of central flexure of an elastic plate placed on an elastic foundation]. Trudy Nauchno-Issledovatel'skikh Uchrezhdenii, Ser. 5, Vyp. 20, p. 30-38.

Smirnov, V. I. 1967. O vozmozhnosti rascheta predela prochnosti ledyanogo pokrova pri kratkovremennykh nagruzkakh [On the possibility of calculating the strength limits of sea ice under loads of short duration]. Okeanologiya, Tom 7, Vyp. 3, p. 428-36. [Translation in Oceanology, Vol. 7, No. 3, 1967 [pub. 1968], p. 331-38.]

Sokolnikov, N. M. 1964 . Prochnost' l'da na r. Yeniseye v rayone Krasnoyarskoy GES v vesennii period [Strength of ice on the Yenisey river in the region of the Krasnoyarsk power station during the spring period]. Trudy Koordinatsionnykh Soveschaniy po Gidrotekhnike, Vyp. 10, p. 1 i $3^{-20}$.

Stearns, S. R. 1957. Aircraft operations on floating ice sheets. Proceedings of the American Society of Civil Engineers. Journal of the Air Transport Division, Vol. 83 , AT 1 , p. ${ }^{1} 3^{2} 5^{-1-1} 3^{2} 5^{-1} 9$.

Stevens, H. W., and Tizzard, W. J. 1969 . Traffic tests on Portage Lake ice. U.S. Cold Regions Research and Engineering Laboratory. Technical Report 99 .

Sundberg-Falkenmark, M. I 1963 . Om isbärighet. Resultat av belastningsförsök på is, utförda av Samarbetsgruppen för isbärighetsförsök 1959-61. Sveriges Meteorologiska och Hydrologiska Institut. Notiser och Preliminära Rapporter. Serie Hydrologi, Nr. I.

Tabata, T., and others. 1967. Studies of the mechanical properties of sea ice. XI. The flexural strength of sea ice in situ, by T. Tabata, K. Fujino and M. Aota. (In Oura, H., ed. Physics of snow and ice: international conference on low temperature science. . . 1966. ... Proceedings, Vol. 1, Pt. 1. [Sapporo], Institute of Low Temperature Science, Hokkaido University, p. 539-5o.)

Tauriainen, M. J. 1970. Port Clarence sea ice testing. Northern Engineer, Vol. 2, No. 1, p. 8-9.

Timoshenko, S. r941. Strength of materials. Vol. 2. New York, D. Van Nostrand Co.

Timoshenko, S., and Woinowsky-Krieger, S. I959. Theory of plates and shells. Second edition. New York, McGrawHill.

U.S. Air Force. Alaskan Air Command. 1968. Establishing airfields on ice. Alaskan Air Command Publication 88-1.

U.S. Corps of Engineers. 1947. Investigation of construction and maintenance of airdromes on ice 1946-1947. Boston, Massachusetts, Soils Laboratory New England Division. [Revised, May 1948.]

Vishnyakov, Kh. Z., and Silantiyev, Yu. M. 1970. Ispol'zovaniye ledyanogo pokrova pri proizvodstve gidrotekhnicheskikh rabot [The utilization of the ice cover during construction of hydro-technical structures]. Transportnoye Stroitel'stvo, No. 9, p. 23-24.

Volkov, G. 1940. Ledovyye aerodromy [Âirfields on ice]. Morskoy Sbornik, Tom 23, No. 3, p. $77-88$.

Voytkovskiy, K. F. r 957 . Eksperimental'nyye issledovaniya plasticheskikh svoystv l'da [Experimental investigation of the plastic properties of ice]. (In Sezonnoye promer zaniye gruntov i primeneniye l'da dlya stroitel'nykh tseley. Moscow, Izdatel'stvo Akademii Nauk SSSR, p. Iо I-36.)

Voytkovskiy, K. F. 1960. Mekhanicheskiye svoystva l'da [Mechanical properties of ice]. Moscow, Izdatel'stvo Akademii Nauk SSSR.

Weeks, W. F., and Anderson, D. L. 1958. An experimental study of strength of young sca ice. Transactions. American Geophysical Union, Vol. 39, No. 4, p. $641-47$. 
Weeks, W. F., and Assur, A. 1967. The mechanical properties of sea ice. U.S. Cold Regions Research and Engineering Laboratory. Cold regions science and engineering. Hanover, N.H., Pt. II, Sect. C 3.

Weeks, W. F., and Assur, A. 1969 . Fracture of lake and sea ice. U.S. Cold Regions Research and Engineering Laboratory. Research Report 269.

Weeks, W. F., and Kovacs, A. Unpublished. On pressure ridges. [U.S. Cold Regions Research and Engineering Laboratory contract report to U.S. Coast Guard, 1970.]

Westergaard, H. M. ${ }^{1} 923$. Om beregning af plader paa elastisk underlag med saerligt henblik paa spørgsmaalet om spaendinger i betonveje. Ingenioren (København), Nr. 42, p. $5^{1} 3^{-24}$.

Westergaard, H. M. 1948. New formulas for stresses in concrete pavements of airfields. Transactions of the American Society of Civil Engineers, Vol. ${ }_{1} 13$, Paper No. 2340, p. 425-39.

Wyman, M. 1950. Deflections of an infinite plate. Canadian Journal of Research, Ser. A. Vol. 28, p. $293-302$.

Yakunin, A. Ye. 1970. Issledovaniye vliyaniya vremeni deystviya nagruzki na nesushchuyu sposobnost' ledyanogo pokrova [The investigation of the effect of the loading time on the bearing capacity of an ice cover]. Novosibirsk, Novosibirskiy Institut Inzhenerov Zheleznodorozhnogo Transporta.

Zubov, N. N. 1942. Osnovy ustroystva dorog na ledyanom pokrove [The basis of road construction on the ice cover]. Moscow, Gidrometeoizdat.

Zubov, N. N. I945. L'dy Arktiki [Arctic ice]. Moscow, Izdatel'stvo Glavsevmorputi.

Zvolinskiy, N. V. I 946 . K voprosu o deformatsii plavayushchego ledyanogo sloya [On the problem of deformation of a floating ice layer]. Trudy Nauchno-Issledovatel'skikh Uchrezhdenii, Ser. 5, Vyp. 20, p. 16-29.

Zylev, B. V. I950. Davleniye l'da na naklonnye ledorezy [Ice pressure upon inclined icebreakers]. Trudy Moskovskogo Ordena Lenina Instituta Inzhenerov Zheleznodorozhnogo Transporta, Tom 74, p. 334-56. 